\title{
Growth response of Hydrangea macrophylla and Ilex crenata cultivars to low- phosphorus controlled-release fertilizers ${ }^{\text {in }}$
}

\author{
Jacob H. Shreckhise ${ }^{a}$, James S. Owen Jr. ${ }^{\text {b,* }}$, Alexander X. Niemiera ${ }^{c}$ \\ ${ }^{a}$ U.S. Department of Agriculture, Agricultural Research Service, Application Technology Research Unit, 1680 Madison Avenue, Wooster, OH, 44691 , United States \\ ${ }^{\mathrm{b}}$ School of Plant and Environmental Sciences, Virginia Tech, Hampton Roads Agricultural Research and Extension Center, Virginia Beach, VA, 23455, United States \\ ${ }^{\mathrm{c}}$ School of Plant and Environmental Sciences, 409 West Campus Drive, 401-A Saunders Hall, Virginia Tech, Blacksburg, VA, 24061, United States
}

\section{A R T I C L E I N F O}

\section{Keywords:}

Hydrangea macrophylla

Ilex crenata

Phosphorus

Controlled-Release fertilizer

Pine bark

Containerized production

\begin{abstract}
A B S T R A C T
In containerized nursery-crop production, conventional phosphorus $(\mathrm{P})$ fertilization amounts are reported to be in excess of plant needs which has resulted in poor $\mathrm{P}$ use efficiency (PUE) and subsequent $\mathrm{P}$ leaching from containers. Phosphorus leaching can be reduced and PUE improved without affecting plant growth by reducing $\mathrm{P}$ fertilization. The objective of this study was to identify the lowest controlled-release fertilizer (CRF)-P content and subsequent pour-through-extracted substrate pore-water P (PWP) concentration that produces maximal shoot growth of two common container-grown nursery crop species, Hydrangea macrophylla 'PIIHM-II' (hydrangea) and Ilex crenata 'Helleri' (holly), in a pine bark substrate. Hydrangea and holly liners were potted into 3.8-L containers containing a pine bark substrate and grown simultaneously in two different Virginia ecoregions, Middle Atlantic Coastal Plain (MACP) and Ridge and Valley (RV). Plants were fertilized with one of five CRF formulations, each containing equal nitrogen $(\mathrm{N})$ and potassium $(\mathrm{K})$ and $0.4 \%, 0.9 \%, 1.3 \%, 1.7 \%$ or $2.6 \%$ (control) P to supply containers with $0.1,0.2,0.3,0.4$ or $0.6 \mathrm{~g} \mathrm{P}$, respectively. In both ecoregions, hydrangea shoot dry weight (SDW) and growth index [i.e., (widest width + perpendicular width + height) $\div 3$, GI] values were maximal in plants fertilized with 0.3 to $0.4 \mathrm{~g}$ P or the control. The lowest CRF-P rate needed for maximal SDW and GI of holly was $0.2 \mathrm{~g} \mathrm{P}$ at the RV site and $0.4 \mathrm{~g} \mathrm{P}$ at the MACP site. Mean PWP concentrations that corresponded with highest SDW were as low as 0.8 and $1.2 \mathrm{mg} \mathrm{L}^{-1}$ for hydrangea and holly, respectively. Results from this research suggest hydrangea requires approximately half the P rate supplied by recommended rates of conventional CRFs. Since the growth response of holly to CRF-P rate at the MACP site was inconsistent with results observed at the RV site and findings in scientific literature, further research is needed to determine the minimum required CRF-P rate for this taxon.
\end{abstract}

\section{Introduction}

Phosphorus (P) runoff from agriculture operations is a leading source of pollution and resulting eutrophication in US surface waters (Boesch et al., 2001; Michalak et al., 2015; USEPA, 2017). In the Chesapeake Bay Watershed, which spans six U.S. states and the District of Columbia, $29 \%$ of agricultural P-inputs are from chemical fertilizers (USEPA, 2010). Hence, P management in crop production is critical from an environmental perspective. If forthcoming $\mathrm{N}$ and $\mathrm{P}$ Total Maximum Daily Load milestones are not met for the Chesapeake Bay Watershed and other impaired waterways, more stringent nutrient load regulations can be expected for agricultural producers therein (Majsztrik and Lea-Cox, 2013).

Agricultural operations can voluntarily contribute to achieving Total Maximum Daily Loads by implementing Best Management Practices (BMPs). In containerized crop production, fertilizing with controlled-release fertilizer (CRF) instead of aqueous or soluble granular forms is among the most widely employed BMPs for fertilizer management by growers in Virginia (Mack et al., 2017) and Alabama (Fain et al., 2000). Relative to other fertilization methods used in nursery crop production, CRFs have been shown to promote higher phosphorus use efficiency (PUE; percent of fertilizer P taken up by

\footnotetext{
Abbreviations: PWP, pore-water phosphorus; MACP, Middle Atlantic Coastal Plain; RV, Ridge and Valley; GI, growth index; GI $\mathrm{f}_{\mathrm{f}}$ growth index at harvest

This publication is a portion of a dissertation submitted by Jacob H. Shreckhise in partial fulfillment of the degree of Doctorate of Philosophy. The use of trade or

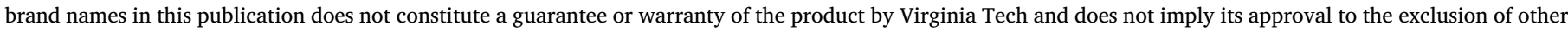
products or vendors that also may be suitable.

* Corresponding author.

E-mail address: jim.owen@vt.edu (J.S. Owen).
} 
plants; Naik et al., 2017) and decrease P leaching from containers (Broschat, 1995; Diara et al., 2014) and subsequent P runoff from a given production area (Sharma and Bolques, 2007).

Despite improved PUE when using CRF relative to other fertilization methods, PUE of CRF-fertilized container-grown nursery crops has been reported to remain between $\approx 27 \%$ and $62 \%$ (Owen et al., 2008; Tyler et al., 1996; Warren et al., 1995, 2001). Multiple containerized crop production studies have shown that $\mathrm{P}$ readily leaches from pine bark substrates during irrigation (Yeager and Barrett, 1984, 1985; Yeager and Wright, 1982a), and current P fertilization amounts exceed plant needs (Ristvey et al., 2007). Thus, relatively low PUE is a consequence of superfluous $\mathrm{P}$ fertilization amounts and inaccessibility of $\mathrm{P}$ to roots due to $\mathrm{P}$ leaching from containers.

Phosphorus use efficiency of containerized crops can be improved without affecting plant growth by reducing P fertilization. In two studies utilizing liquid-fertilization, Ristvey et al. (2004, 2007) observed increased PUE of containerized Rhododendron L. 'Karen' grown in a pine bark-peat substrate from $\approx 15 \%$ to $\approx 45 \%$ by decreasing P from 25 to $5 \mathrm{mg}$ per week when applied $\mathrm{N}$ was non-limiting for growth (i.e., 100 to $250 \mathrm{mg} \mathrm{L}^{-1} \mathrm{~N}$ ). In both studies, shoot growth was unaffected by $P$ fertilizer level. When using a CRF, Owen et al. (2008) found that reducing P from 1.0 to $0.5 \mathrm{~g}$ per container improved PUE of Cotoneaster dammeri Schnied. 'Skogholm' by $11 \%$ without affecting shoot growth when grown in a pine bark substrate amended with $11 \%$ builder's sand (by volume).

Best Management Practices for CRF-fertilized container nursery crops (Bilderback et al., 2013) cite that pore-water P (PWP) concentrations, as measured using the pour-through extraction method, of $5-10 \mathrm{mg} \mathrm{L}^{-1} \mathrm{P}$ be maintained for non-limiting crop growth. However, studies have shown that some woody taxa can sustain maximal growth when pour-through leachate $\mathrm{P}$ is consistently $<5 \mathrm{mg} \mathrm{L}^{-1}$. Groves et al. (1998a; and 1998b) found that the CRF type (i.e., resin-coated P or polymer-coated P) that produced highest shoot dry weight of Cotoneaster dammeri 'Skogholm' grown in a pine bark substrate had $<3 \mathrm{mg} \mathrm{L}^{-1}$ P in pour-through leachate. Similarly, Matysiak (2015) observed that pour-through P concentrations for CRF-fertilized Euonymus japonicus Thunb. 'Ovatus Aureus' and Rhododendron L. 'Geisha Orange' associated with highest quality ratings and shoot fresh weight had $\leq 2.6 \mathrm{mg} \mathrm{L}^{-1} \mathrm{P}$ in pour-through leachate when grown in a sphagnum peat substrate.

Few studies have specifically assessed the lowest necessary P content in CRFs and resulting PWP concentration for maximal growth of container-grown nursery crops. Leonard et al. (2007) grew Codiaeum variegatum (L.) Blume var. pictum (Lodd.) Müll. Arg. 'Mammy' and Chrysobalanus icaco L. potted in a pine bark-peat substrate and fertilized with CRF containing $18 \% \mathrm{~N}, 10 \% \mathrm{~K}$ and $0 \%, 0.4 \%, 1.3 \%$, or $2.6 \% \mathrm{P}$. In both taxa, growth index values were highest in plants fertilized with CRF granules containing at least $0.4 \% \mathrm{P}$ in which pour-through leachate concentrations were 0.3 to $0.7 \mathrm{mg} \mathrm{L}^{-1}$. However, P nutrition of tropical plant taxa may differ from that of temperate species. The objective of this study was to identify the lowest CRF-P content and subsequent substrate PWP concentration that produces maximal shoot growth of two common container-grown nursery crop species, hydrangea and holly, in a pine bark substrate.

\section{Materials and methods}

This study was replicated simultaneously in two different ecoregions, the Middle Atlantic Coastal Plain (MACP) and Ridge and Valley (RV). The MACP site was at the Virginia Tech Hampton Roads Agriculture Research and Extension Center in Virginia Beach, Virginia (latitude $36^{\circ} 53^{\prime} 31^{\prime \prime} \mathrm{N}$; longitude $76^{\circ} 10^{\prime} 44^{\prime \prime} \mathrm{W}$; $8 \mathrm{~m}$ elevation; USDA Plant Hardiness Zone 8a) and the RV site was at the Urban Horticulture Center in Blacksburg, VA (latitude $37^{\circ} 12^{\prime} 59^{\prime \prime} \mathrm{N}$; longitude $80^{\circ} 27^{\prime} 50^{\prime \prime} \mathrm{W}$; $629 \mathrm{~m}$ elevation; USDA Plant Hardiness Zone 6b). Daily rainfall and temperature data, obtained from the on-site Virginia Agricultural Experimental Station Mesonet weather station, are illustrated in Fig. 1.
On 14 May 2015, rooted stem cuttings of Ilex crenata Thunb. 'Helleri' (holly) were acquired in 18-cell flats (three cuttings per cell) from Saunders Brothers Nursery, Piney River, VA. Ilex crenata Thunb. 'Helleri' is a broadleaf-evergreen shrub with small leaves and a compact, mounded form (Niemiera, 2009). Rooted stem cuttings of Hydrangea macrophylla (Thunb.) Ser. 'PIIHM-II' (Bloomstruck ${ }^{\circledR}$ ) were received 15 May 2015 from Bailey Nursery, Yamhill, OR in 45-cell flats (one cutting per cell). Hydrangea macrophylla (Thunb.) Ser.'PIIHM-II' (Bloomstruck ${ }^{\circledast}$ ) is a remontant flowering cultivar with mophead-type flowers; flower color varies from dark pink to violet depending on soil aluminum availability (Dirr and Kardos, 2015). This cultivar is differentiated from the species by its red stems, dark green leaves and its resistance to powdery mildew. Rooted stem cuttings of each taxon were taken to the MACP and RV sites.

\subsection{Middle Atlantic Coastal Plain site}

On 1 June 2015 (day 0), rooted stem cuttings within each cell were separated and roots rinsed with a high-pressure water stream to remove substrate and fertilizer. Bare-root plants were then potted individually into $3.8 \mathrm{~L}$ black plastic containers (\#1, Nursery Supplies, Chambersburg, PA). Substrate used for potting holly and hydrangea consisted of aged pine bark (Sun Gro, Agawam, MA) amended with $0.89 \mathrm{~kg} \mathrm{~m}^{-3}$ of a granular micronutrient fertilizer (Micromax, Everris, Dublin, $\mathrm{OH}$ ), $2.08 \mathrm{~kg} \mathrm{~m}^{-3}$ ground dolomitic limestone [97\% calcium carbonate equivalent (CCE), Rockydale Quarries Corporation, Roanoke, VA] and $2.08 \mathrm{~kg} \mathrm{~m}^{-3}$ pulverized dolomitic limestone (94\% CCE, Old Castle Lawn and Garden, Thomasville, PA). Amendments were thoroughly hand-mixed into substrate to ensure homogeneity. Container capacity and air space of the substrate were $55.8 \%$ and $19.4 \%$, respectively, and bulk density was $0.15 \mathrm{~g} \cdot \mathrm{cm}^{-3}$ (NCSU porometer method, Fonteno et al., 1995).

Each plant received $3.65 \pm 0.04$ SE $g \mathrm{~N}$ from either $20 \mathrm{~g}$ of one of four low-P CRF treatments (experimental CRFs) or $24 \mathrm{~g}$ of a standard CRF used in Virginia nurseries (control; Table 1). Fertilizer was delivered by surface application followed by hand-incorporation of CRF in the top $2.5 \mathrm{~cm}$ of substrate. All four experimental CRF treatments were 8- to 9-month heterogeneous formulations (Harrell's LLC, Lakeland, FL), blended specifically for this study. In addition to N, P and $\mathrm{K}$, all four experimental CRFs contained $1.24 \%$ magnesium $(\mathrm{Mg}), 4.38 \%$ sulfur $(\mathrm{S}), 0.11 \%$ copper $(\mathrm{Cu}), 1.26 \%$ iron $(\mathrm{Fe}), 0.12 \%$ manganese $(\mathrm{Mn})$, $0.003 \%$ molybdenum (Mo) and $0.11 \%$ zinc ( $\mathrm{Zn}$ ). The control CRF (8- to 9-month formulation) contained $1.3 \% \mathrm{Mg}, 6.3 \% \mathrm{~S}, 0.08 \% \mathrm{Cu}, 0.32 \%$ Fe, $0.13 \% \mathrm{Mn}, 0.01 \%$ Mo and $0.08 \% \mathrm{Zn}$.

All holly were pruned to a width and height of $10.4 \mathrm{~cm}$ and hydrangea to a width of 13.8 and height of $17.8 \mathrm{~cm}$. Plants were then placed $0.15 \mathrm{~m}$ apart on an outdoor gravel pad in a completely randomized design (CRD) with seven replications per treatment. Due to taxaspecific irrigation requirements, hydrangea and holly were grown under separate irrigation systems. All plants were overhead irrigated with impact sprinklers [Model 2045-PJ SBN-1, $3.18 \mathrm{~mm}$ orifice (holly) or $3.97 \mathrm{~mm}$ orifice (hydrangea), Rain Bird, Azusa, CA)] on $122 \mathrm{~cm}$ risers daily or as needed in two cycles, the first at $1200 \mathrm{~h}$ and the second at $1600 \mathrm{~h}$. On average, hydrangea and holly received $1.1 \pm 0.47 \mathrm{SE} \mathrm{cm}$ $(\mathrm{n}=15)$ and $0.56 \pm 0.43 \mathrm{sE} \mathrm{cm}(\mathrm{n}=12)$ water, respectively, per irrigation cycle; however, irrigation rate was adjusted periodically based on leaching fraction. At 31 DAI, irrigation distribution uniformity was measured to be $85 \%$ for both the hydrangea and holly irrigation systems. Irrigation distribution uniformity was determined by placing a minimum of twelve 100 -mL cups in an evenly spaced grid to capture water applied in a 15-min irrigation cycle. The distribution uniformity was then calculated as described by Mathers et al. (2005): (average volume in the lowest quartile $\div$ average volume) $\times 100$. Leaching fraction (volume leached $\div$ volume applied) was measured on three replications per taxa at 42,52 and $88 \mathrm{DAI}$ for hydrangea and 30,52 and 88 DAI for holly. Volume leached was determined by suspending a 

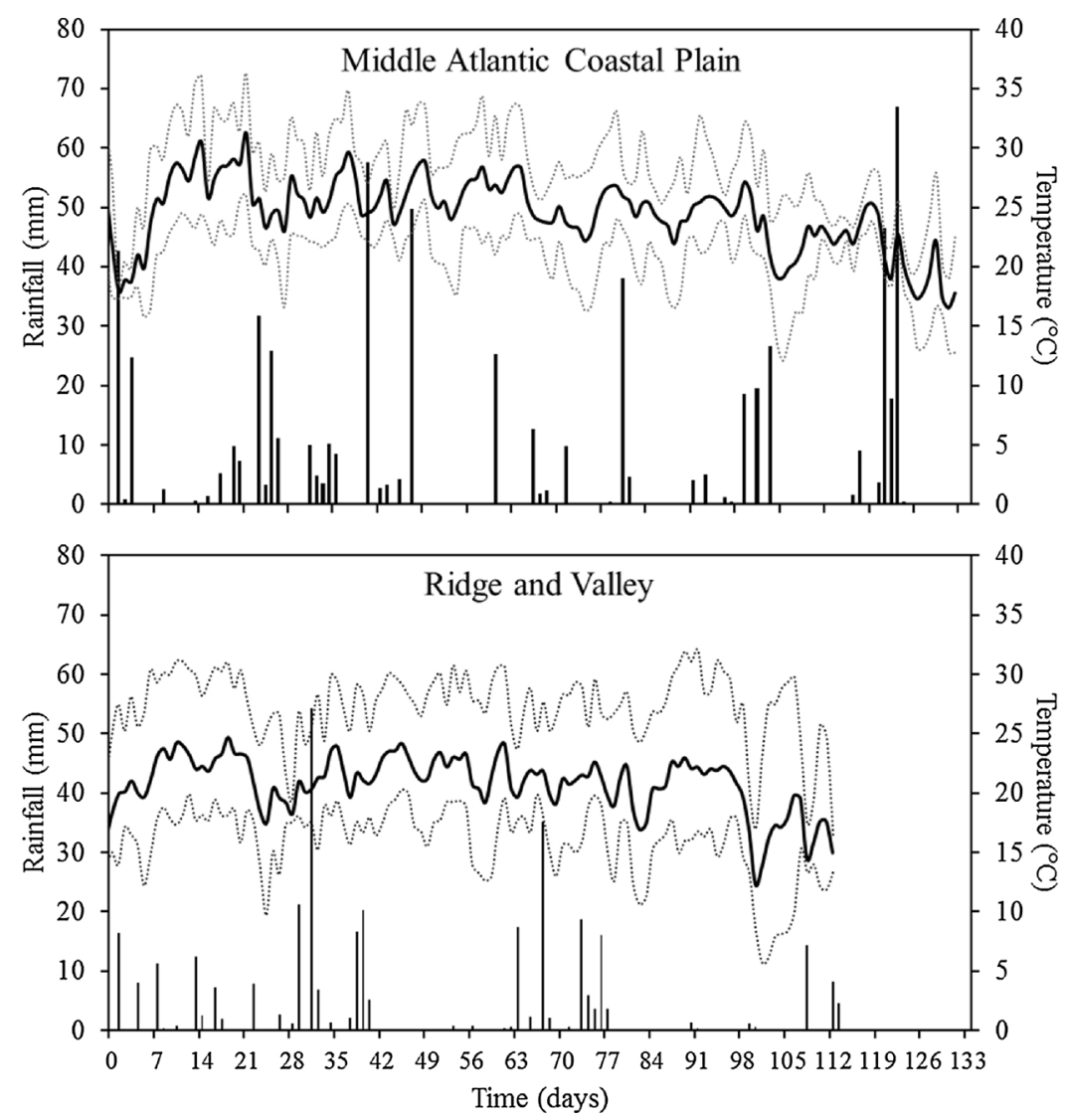

Fig. 1. Daily rainfall (bars) and maximum (dotted line), mean (solid line) and minimum (dotted line) daily temperature at the Middle Atlantic Coastal Plain (MACP) and Ridge and Valley (RV) sites over the course of the experiment. For the MACP site, days 0 and 133 were on 6 June 2015 and 10 October 2015, respectively, and for the RV site, days 0 and 113 were on 4 June 2015 and 25 September 2015, respectively.
Table 1

Sources and amount $(\mathrm{g})$ of nitrogen $(\mathrm{N})$, phosphorus $(\mathrm{P})$ and potassium $(\mathrm{K})$ supplied as polymer-coated controlled-release fertilizer (CRF) applied to each hydrangea and holly grown in 3.8-L containers in a pine bark substrate.

\begin{tabular}{lllllll}
\hline Fertilizer treatmentss & $\mathrm{NH}_{4}-\mathrm{N}$ & $\mathrm{NO}_{3}-\mathrm{N}$ & Urea-N & Total N & $\mathrm{P}$ & $\mathrm{K}$ \\
\hline $15 \mathrm{~N}-2.6 \mathrm{P}-10 \mathrm{~K}$ (control) $^{\mathrm{y}}$ & 1.98 & 1.62 & 0.00 & 3.60 & 0.63 & 2.39 \\
$18 \mathrm{~N}-1.7 \mathrm{P}-10 \mathrm{~K}$ & 0.30 & 0.25 & 3.14 & 3.69 & 0.10 & 2.04 \\
$18 \mathrm{~N}-1.3 \mathrm{P}-10 \mathrm{~K}$ & 0.34 & 0.25 & 3.06 & 3.64 & 0.18 & 2.04 \\
$18 \mathrm{~N}-0.9 \mathrm{P}-10 \mathrm{~K}$ & 0.39 & 0.25 & 3.06 & 3.69 & 0.27 & 2.04 \\
$18 \mathrm{~N}-0.4 \mathrm{P}-10 \mathrm{~K}$ & 0.43 & 0.25 & 2.97 & 3.65 & 0.36 & 2.04 \\
\hline
\end{tabular}

${ }^{\mathrm{z}}$ Nitrogen, phosphorus and potassium in the four experimental fertilizers were derived from ammonium nitrate, ammonium phosphate, urea and potassium sulfate.

y Nitrogen, phosphorus and potassium in the control are derived from ammonium nitrate, ammonium phosphate, and potassium sulfate.

containerized plant above a catchment vessel to collect leachate during an irrigation event. A plastic skirt was wrapped around the planted container and draped over the catchment vessel to ensure irrigation water could not fall directly into the catchment vessel. An empty $3.8 \mathrm{~L}$ container, lined with a plastic bag, was placed next to each catchment vessel to collect and measure irrigation volume applied. Over the course of the study, mean leaching fractions for hydrangea and holly were $0.72 \pm 0.07 \mathrm{SE}$ and $0.39 \pm 0.11 \mathrm{SE}$, respectively.

At 16, 28, 52, 88 and 115 DAI, substrate pore-water (i.e., capillary water retained within and between substrate particles) was extracted from four replications per treatment via the pour-through method (Wright, 1986) and analyzed for $\mathrm{P}$ concentrations, $\mathrm{pH}$ and electrical conductivity (EC). Pour-through extracts were attained by handpouring $120 \mathrm{~mL}$ deionized water over the surface of the substrate $\approx 1 \mathrm{~h}$ following a normal irrigation event and collecting at least $50 \mathrm{~mL}$ of subsequent leachate for analyses. To measure substrate pore-water and irrigation water nutrient concentrations, an $8-\mathrm{mL}$ aliquot of each sample was filtered $(0.2 \mu \mathrm{m}, 30 \mathrm{~mm}$ syringe filter; Thermo Fisher Scientific, Beverly, MA) then stored at $-18{ }^{\circ} \mathrm{C}$ until ion analysis. Porewater and irrigation samples were thawed and analyzed for phosphate $\left(\mathrm{PO}_{4}{ }^{3-}\right)$ concentration in pore-water samples and $\mathrm{NH}_{4}{ }^{+}, \mathrm{Ca}^{2+}, \mathrm{Mg}^{2+}$, $\mathrm{K}^{+}, \mathrm{NO}_{2}{ }^{-}, \mathrm{NO}_{3}{ }^{-}$and $\mathrm{PO}_{4}{ }^{3-}$ concentrations in irrigation water using two ion chromatography (IC) systems. The IC systems used to determine anion concentrations (ICS-2100, Thermo-Fisher Scientific) and cation concentrations (ICS-1600, Thermo-Fisher Scientific) utilized respective $4 \times 250 \mathrm{~mm}$ (i.d. $\times$ length) anion- and cation-exchange columns (AS19 and CS12 A, respectively, Thermo Fisher Scientific) at $35^{\circ} \mathrm{C}$ and an autosampler (AS-AP, Thermo Fisher Scientific) on a $25 \mu \mathrm{L}$ sample loop. In addition, the ICS-2100 was equipped with a metal trap column (MFC-1, Thermo Fisher Scientific) to remove metals that may interfere with accurate detection of the aforementioned anions. Porewater $\mathrm{NO}_{3}{ }^{-}$and $\mathrm{K}^{+}$concentrations were not assessed because concentrations of these ions were often higher than detection limits (i.e., $136 \mathrm{mg} \mathrm{L}^{-1}$ ) and diluting samples would have compromised $\mathrm{PO}_{4}{ }^{3-}$ data. Irrigation water $(\mathrm{n}=6$; collected $16 \mathrm{DAI})$ contained $<0.25 \mathrm{mg}$ $\mathrm{L}^{-1} \mathrm{NH}_{4}^{+}, 14.08 \pm 0.44 \mathrm{sE} \mathrm{mg} \cdot \mathrm{L}^{-1} \mathrm{Ca}^{2+}, 3.93 \pm 0.17 \mathrm{SE} \mathrm{mg} \cdot \mathrm{L}^{-1}$ $\mathrm{Mg}^{2+}, 3.93 \pm 0.23 \mathrm{SE} \mathrm{mg} \cdot \mathrm{L}^{-1} \mathrm{~K}^{+},<0.25 \mathrm{mg} \mathrm{L}^{-1} \mathrm{NO}_{2}{ }^{-}, 13.64 \pm 1.84$ SE $\mathrm{mg} \cdot \mathrm{L}^{-1} \mathrm{NO}_{3}{ }^{-}$and $<0.25 \mathrm{mg} \mathrm{L}^{-1} \mathrm{PO}_{4}{ }^{3-}$. Total alkalinity of the irrigation water was measured by Brookside Laboratories Inc. (New Bremen, $\mathrm{OH}$ ) to be $50 \mathrm{mg} \mathrm{L}^{-1}$. Electrical conductivity and $\mathrm{pH}$ were measured using a benchtop meter (Orion 4-Star Plus pH/Conductivity Meter, Thermo Fisher Scientific) equipped with a 4-Electrode Conductivity Cell (DuraProbe, Thermo Fisher Scientific) and a double junction pH electrode (9102 A P, AquaPro, Orion, Thermo Fisher Scientific). All pH and EC analyses were completed within twelve hours of collecting pore-water samples. Growth index [GI; i.e., (height + widest width + perpendicular width)/3] was measured for all plants 15,52 , 88 and 130 DAI (Wright et al., 2006).

At day 130, two replications from each treatment for both taxa were removed from the study due non-treatment-related poor health. Foliar 
Table 2

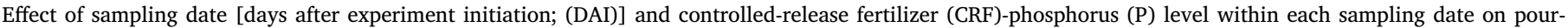
through-extracted pore-water P concentration $(n=4)$ of hydrangea and holly grown at the Middle Atlantic Coastal Plain site (Virginia Beach, VA).

\begin{tabular}{|c|c|c|c|c|c|c|c|}
\hline \multirow[b]{2}{*}{ CRF-P (g) } & \multicolumn{5}{|c|}{ Pore-water P conc. (mg. $\left.\mathrm{L}^{-1}\right)$} & \multirow[b]{2}{*}{$P$-value ${ }^{\mathrm{x}}$} & \multirow[b]{2}{*}{ HSD } \\
\hline & 16 DAI & 28 DAI & $\begin{array}{l}52 \text { DAI } \\
\text { hydrangea }\end{array}$ & 88 DAI & 114 DAI & & \\
\hline control & 0.37 & 0.08 & $0.79 \mathrm{ab}^{\mathrm{z}}$ & $3.70 \mathrm{a}$ & 5.99 & 0.0559 & - \\
\hline 0.1 & 0.26 & 0.08 & $0.08 \mathrm{c}$ & $0.08 \mathrm{~b}$ & 0.10 & 0.0092 & 0.22 \\
\hline 0.2 & 0.67 & 0.41 & $0.21 \mathrm{bc}$ & $0.12 \mathrm{~b}$ & 0.18 & 0.0785 & - \\
\hline 0.3 & 0.77 & 0.54 & $0.76 \mathrm{ab}$ & $0.85 \mathrm{~b}$ & 1.14 & 0.8665 & - \\
\hline 0.4 & 1.61 & 0.73 & $1.01 \mathrm{a}$ & $1.75 \mathrm{ab}$ & 0.65 & 0.4683 & - \\
\hline \multicolumn{8}{|l|}{$P$-values } \\
\hline ANOVA & 0.2188 & 0.0636 & 0.0027 & 0.0021 & 0.0977 & & \\
\hline $\mathrm{L}_{0.1-0.4^{\mathrm{y}}}$ & 0.0514 & 0.0232 & 0.0002 & 0.0063 & 0.0495 & & \\
\hline $\mathrm{Q}_{0.1-0.4}$ & \multicolumn{6}{|c|}{ holly } & \\
\hline control & 1.25 & 0.33 & $0.41 \bar{b}$ & $9.99 \mathrm{a}$ & $7.55 \mathrm{a}$ & 0.0002 & 5.83 \\
\hline 0.1 & 1.22 & 0.10 & $0.08 \mathrm{~b}$ & $0.08 \mathrm{~b}$ & $0.09 \mathrm{~b}$ & $<0.0001$ & 0.25 \\
\hline 0.2 & 1.92 & 1.08 & $0.42 \mathrm{~b}$ & $1.05 \mathrm{~b}$ & $0.42 \mathrm{~b}$ & 0.2694 & - \\
\hline 0.3 & 1.27 & 1.27 & $0.65 \mathrm{~b}$ & $0.49 \mathrm{~b}$ & $1.74 \mathrm{~b}$ & 0.2988 & - \\
\hline 0.4 & 3.02 & 2.87 & $2.12 \mathrm{a}$ & $3.12 \mathrm{~b}$ & $1.74 \mathrm{~b}$ & 0.9196 & - \\
\hline \multicolumn{8}{|l|}{$P$-values } \\
\hline ANOVA & 0.1874 & 0.2725 & 0.0015 & $<0.0001$ & 0.0041 & & \\
\hline $\mathrm{L}_{0.1-0.4}$ & 0.1269 & 0.0670 & 0.0008 & 0.0247 & 0.0021 & & \\
\hline $\mathrm{Q}_{0.1-0.4}$ & 0.2398 & 0.1897 & 0.0014 & 0.054 & 0.0097 & & \\
\hline
\end{tabular}

${ }^{\mathrm{z}}$ Letters within columns separate means by Tukey's Honest Significant Difference at $\mathrm{P} \leq 0.05$.

y Only the experimental fertilizers were included in linear and quadratic regression analysis.

${ }^{x}$ P-values were attained via ANOVA to assess the changes in PWP concentrations over time within CRF treatments. Tukey's Honest Significant Difference (HSD) value is provided for means comparisons within rows.

samples were harvested from each remaining plant as described in Bryson et al. (2014) for tissue nutrient analysis. For hydrangea, tissue samples consisted of 12 to 15 leaf blades from recently matured leaves. Holly tissue samples were twelve $3.1-\mathrm{cm}$ terminal stem cuttings. Tissue samples were triple-rinsed with deionized water then visually inspected to ensure samples were clean of possible contaminants (i.e., substrate particles). Foliar samples were then oven-dried $\left(60^{\circ} \mathrm{C}\right)$, weighed and analyzed for N, P and K concentrations (Brookside Laboratories, New Bremen, $\mathrm{OH}$ ). Tissue sample dry weights were included in final shoot dry weight (SDW) calculations.

At 133 DAI, shoots (i.e., above-substrate level) were severed, ovendried $\left(60^{\circ} \mathrm{C}\right)$ and weighed for SDW. Substrate was then removed from the roots using a high-pressure water stream, and roots were oven-dried $\left(60^{\circ} \mathrm{C}\right)$ and weighed for root dry weight (RDW). Due to the labor required to remove substrate particles from hydrangea roots, three replications from each treatment were selected at random for hydrangea RDW. All five replications were included to obtain holly RDW.

\subsection{Ridge and valley site}

Materials and methods for the RV site were similar to those used at the MACP site with the follow exceptions. Hydrangea and holly were potted on 4 June 2015 (day 0) and then placed on an outdoor gravel pad under two separate overhead-irrigation systems $(137 \mathrm{~cm}$ risers, upright mini-Wobblers, $2.78 \mathrm{~mm}$ \#7 orifice, Senninger, Clermont, FL). On average, hydrangea and holly received $0.43 \pm 0.14 \mathrm{sE} \mathrm{cm}(\mathrm{n}=15)$ or $0.41 \pm 0.13 \mathrm{sE} \mathrm{cm}(\mathrm{n}=18)$ irrigation, respectively. Irrigation distribution uniformity was measured 34 DAI to be $93 \%$ or $94 \%$ for the hydrangea and holly irrigation systems, respectively. Leaching fraction was measured on three replications per taxa at 36, 60 and 91 DAI for hydrangea and 36, 60 and 104 DAI for holly. Mean leaching fraction values for hydrangea and holly were $0.49 \pm 0.09 \mathrm{SE}$ and $0.39 \pm 0.09$ $\mathrm{SE}$, respectively.

Substrate pore-water samples were collected 19, 36, 61, 91 and 109 DAI for analysis of $\mathrm{pH}, \mathrm{EC}$ and $\mathrm{PO}_{4}{ }^{3-}$ concentrations. Irrigation water ( $\mathrm{n}=3$; collected $110 \mathrm{DAI}$ ) contained $0.46 \pm 0.001 \mathrm{sE} \mathrm{mg} \cdot \mathrm{L}^{-1} \mathrm{NH}_{4}{ }^{+}$,

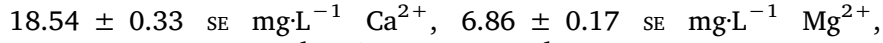
$2.04 \pm 0.02$ SE mg. $\mathrm{L}^{-1} \mathrm{~K}^{+},<0.25 \mathrm{mg} \mathrm{L}^{-1} \mathrm{NO}_{2}{ }^{-}, 1.29 \pm 0.07 \mathrm{SE}$ $\mathrm{mg} \cdot \mathrm{L}^{-1} \mathrm{NO}_{3}{ }^{-}$and $0.39 \pm 0.002 \mathrm{SE} \mathrm{mg} \cdot \mathrm{L}^{-1} \mathrm{PO}_{4}{ }^{3-}$. Total alkalinity of the irrigation water was measured by Brookside Laboratories Inc. (New Bremen, $\mathrm{OH}$ ) to be $28 \mathrm{mg} \mathrm{L}^{-1}$. Electrical conductivity and $\mathrm{pH}$ were measured using a pH, EC and TDS meter (HI9811, Hanna Instruments Inc., Woonsocket, RI).

All replications were kept in the study. Foliar samples for tissue nutrient analysis were harvested from each plant 111 DAI, and shoots and roots were harvested 113 DAI. Roots were harvested from four replications per treatment for hydrangea due to difficulty in efficiently separating substrate particles from roots.

\subsection{Statistical analysis}

To assess treatment effects, including the control CRF, data were subjected to analysis of variance (ANOVA), and post-hoc means comparison was accomplished using the Tukey-Kramer Honest Significant Difference test. Linear and quadratic regression were performed to assess the effect of experimental CRF-P rate (i.e., 0.1 to $0.4 \mathrm{~g} P$ per container) on response variables measured. The multivariate approach to repeated measures analysis was used to affirm that a time $\times$ CRF-P rate interaction existed within each taxa. Since the time $\times$ CRF-P rate interaction was significant $(P<0.05)$ for each taxa in both ecoregions, ANOVA and subsequent Tukey's HSD means separation was used to assess simple effects of CRF-P rate at each measurement date. Since PWP concentrations, $\mathrm{pH}$ and EC were measured on four randomly-selected replications within each treatment, repeated measures analysis was not necessary. When pooled across sampling dates, PWP data were log transformed to meet the constant variance assumption. After ANOVA and regression P-values were attained, mean PWP levels were converted back to original measured values. Correlations were determined using the Pearson correlation coefficient (r). All data were processes using JMP Pro 13 (SAS Institute Inc.). 

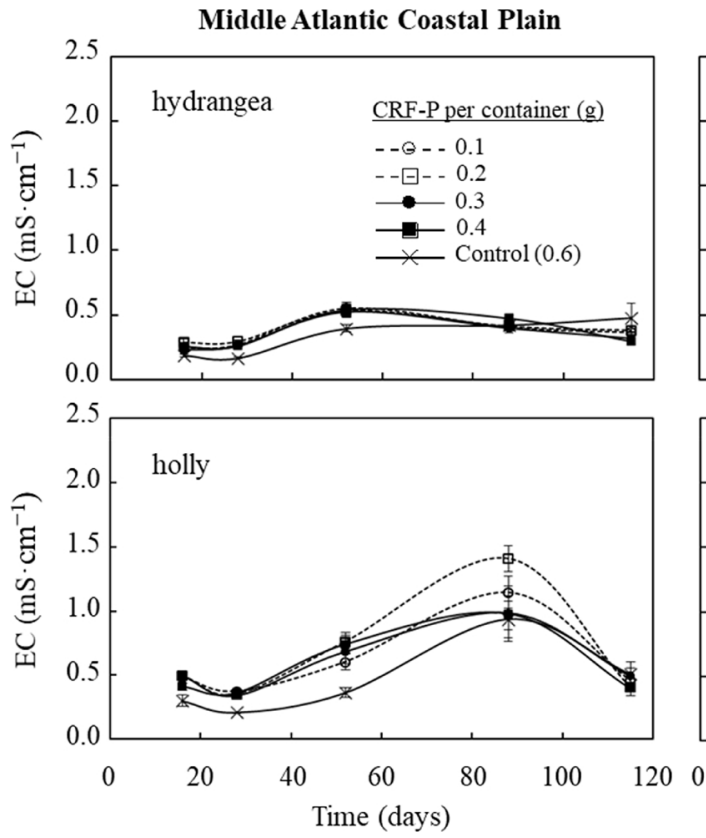

\section{Results and discussion}

\subsection{Middle Atlantic Coastal Plain}

\subsubsection{Pore-water phosphorus}

Pore-water $\mathrm{P}$ concentrations were the same across CRF treatments at $16 \mathrm{DAI}$ for hydrangea $\left(0.74 \pm 0.20 \mathrm{SE} \mathrm{mg} \cdot \mathrm{L}^{-1}\right)$ and at 16 and $28 \mathrm{DAI}$ for holly (1.74 $\pm 0.28 \mathrm{SE}$ and $1.13 \pm 0.42 \mathrm{sE} \mathrm{mg} \cdot \mathrm{L}^{-1}$, respectively); at all sampling dates thereafter, PWP levels increased linearly for both taxa with increasing CRF-P rate (Table 2). For both taxa, PWP levels of the control CRF were the same as those of the $0.2 \mathrm{~g}$ P CRF until $88 \mathrm{DAI}$, despite three times more $P$ in the control CRF. At 88 DAI, PWP concentrations of holly fertilized with the control CRF were over three times that of any other treatment, whereas PWP concentrations of hydrangea fertilized with the control were the same as in those given $0.4 \mathrm{gP}$ treatment. These data suggest $\mathrm{P}$ in the control CRF had a different release pattern, with a delayed release compared to the experimental CRFs. This assessment is supported by the $\approx 2300 \%$ increase in PWP concentration from 52 to 88 DAI for holly fertilized with the control; yet, in all other treatments, PWP was unchanged between 52 and 88 DAI. In addition, pore-water EC (Fig. 2) was consistently lower in holly fertilized with the control CRF compared to the experimental fertilizers. A possible explanation for the differing release between the control and experimental CRFs may be related to their homogenous and heterogenous nature, respectively. In the control CRF, each granule contained a combination of all listed mineral nutrient salts, whereas the experimental fertilizers contained individually-coated prills of monoammonium phosphate $\left(\mathrm{NH}_{4} \mathrm{H}_{2} \mathrm{PO}_{4}\right)$, urea $\left(\mathrm{CH}_{4} \mathrm{~N}_{2} \mathrm{O}\right)$ and potassium sulfate $\left(\mathrm{K}_{2} \mathrm{SO}_{4}\right)$. Several studies assessing release of individual nutrients from homogeneous polymer-coated CRF products (similar to our control CRF) have reported a lag in P release (Broschat, 2005; Broschat and Moore, 2007; Du et al., 2006; Newman et al., 2006). However, little evidence exists that individually-coated $\mathrm{NH}_{4} \mathrm{H}_{2} \mathrm{PO}_{4}, \mathrm{CH}_{4} \mathrm{~N}_{2} \mathrm{O}$ and $\mathrm{K}_{2} \mathrm{SO}_{4}$ prills, all of which are common in a heterogeneous CRF, have belated release.

For all treatments except for hydrangea and holly fertilized with $0.1 \mathrm{~g} \mathrm{P}$ and holly fertilized with the control, PWP concentrations were the same over time (Table 2). Pore-water P concentrations of hydrangea and holly fertilized with $0.1 \mathrm{~g}$ P were highest at $16 \mathrm{DAI}$, then decreased to levels consistently near or below detection limits (i.e., $\leq$ $0.08 \mathrm{mg} \mathrm{L}^{-1} \mathrm{PO}_{4}-\mathrm{P}$ ). The nearly non-detectable PWP concentrations for
Ridge and Valley

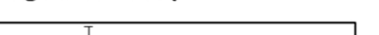
(CRF) treatment [g phosphorus (P) per container] on substrate pore-water electrical conductivity (EC) over time for hydrangea and holly grown at the Middle Atlantic Coastal Plain $(n=4)$ and Ridge and Valley $(n=4)$ sites for 133 and 113 days, respectively. Vertical bars indicate SE.GR2
3.1.2. Growth index and carbon allocation
Phosphorus treatment effect on hydrangea and holly GI was first apparent at $130 \quad(\mathrm{~F}=6.59 ; \quad \mathrm{P}<0.0001)$ and $88 \quad(\mathrm{~F}=8.47$; $\mathrm{P}=0.0004$ ) DAI, respectively (Fig. 3). The delayed growth response of hydrangea to the varying $P$ rates and the apparent negative GI values at 52 DAI are attributed to transplant stress that resulted in leaf-drop, which suspended growth as plants recovered. From 52-130 DAI, GI of both taxa increased linearly $(\mathrm{P}<0.0001)$ for all treatments except $0.1 \mathrm{gP}$, in which GI responded quadratically. The quadratic growth trend over time and non-detectable PWP concentrations (i.e., $\leq$ $0.08 \mathrm{mg} \mathrm{L}^{-1} \mathrm{PO}_{4}-\mathrm{P}$; Table 2) after 52 DAI for holly fertilized with $0.1 \mathrm{gP}$ indicates $\mathrm{P}$ was limiting shoot growth.

Hydrangea and holly SDW had strong, positive correlations with respective final $\mathrm{GI}\left(\mathrm{GI}_{\mathrm{f}}\right.$; $\mathrm{GI}$ at harvest) values $(\mathrm{r}=0.89$ and 0.81 , respectively). Hydrangea $\mathrm{GI}_{\mathrm{f}}$ and SDW values (Table 3 ) were highest in those fertilized with 0.3 to $0.4 \mathrm{~g}$ P or the control, and holly SDW and $\mathrm{GI}_{\mathrm{f}}$ values were maximal in plants given $0.4 \mathrm{~g}$ P. The corresponding mean PWP concentrations, pooled across sampling dates (Table 3), associated with the highest $\mathrm{GI}_{\mathrm{f}}$ and SDW values were $0.8-2.2 \mathrm{mg} \mathrm{L}^{-1} \mathrm{P}$ for hydrangea and $2.6 \mathrm{mg} \mathrm{L}^{-1} \mathrm{P}$ for holly. Shoot dry weight and $\mathrm{GI}_{\mathrm{f}}$ values increased quadratically for hydrangea and linearly for holly with increasing experimental CRF-P rate. The quadratic response of $\mathrm{GI}_{\mathrm{f}}$ and SDW to increasing CRF-P rate for hydrangea indicates CRF-P levels were at or approaching sufficiency. The linear increase in holly $\mathrm{GI}_{\mathrm{f}}$ and SDW with increasing $\mathrm{P}$ rate suggests that $>0.4 \mathrm{~g}$ CRF-P or $>2.6 \mathrm{mg}$ $\mathrm{L}^{-1} \mathrm{PWP}$ may have resulted in greater shoot growth than that observed in this study. In a liquid feed study performed by Shreckhise et al. (2018), GI of Ilex crenata 'Helleri' was the same for mean pour-through PWP concentrations between 0.1 and $4.6 \mathrm{mg} \mathrm{L}^{-1}\left(1-6 \mathrm{mg} \mathrm{L}^{-1} \mathrm{P}\right.$ 
Middle Atlantic Coastal Plain
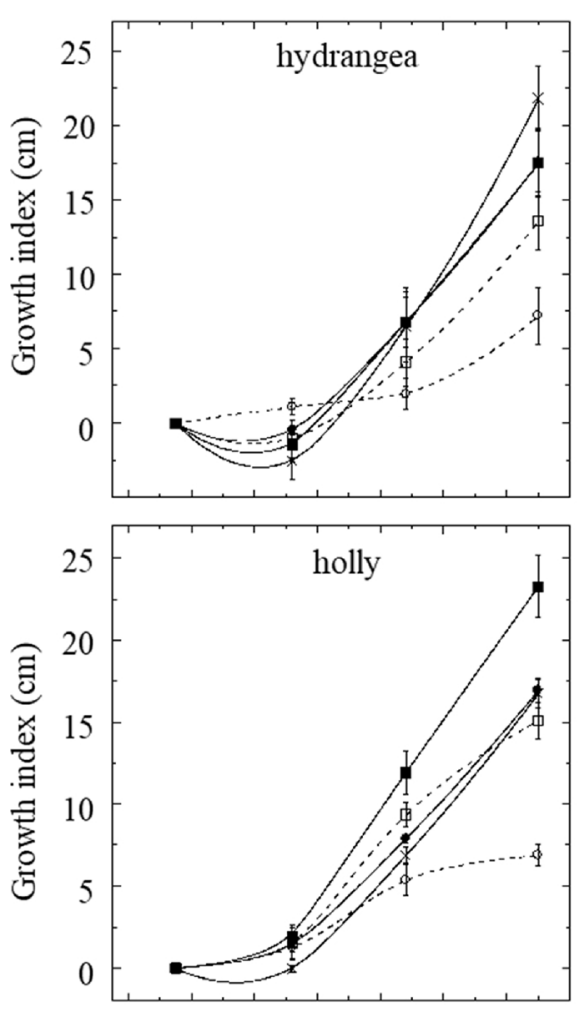

$\begin{array}{lllllll}0 & 20 & 40 & 60 & 80 & 100 & 120\end{array}$
Ridge and Valley
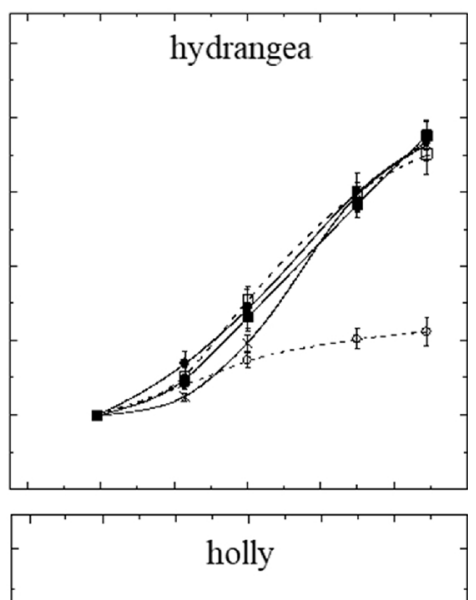

CRF-P per container ( $\mathrm{g})$

$--\ominus-0.1$

$--\boxminus--0.2$

$\longrightarrow 0.3$

$\longrightarrow$ Control $(0.6)$

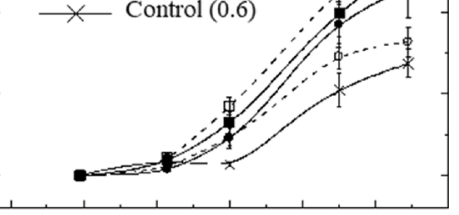

$\begin{array}{llllll}0 & 20 & 40 & 60 & 80 & 100\end{array}$

Time (days)

Fig. 3. Effect of controlled-release fertilizer (CRF) treatment [g phosphorus (P) per container] on growth index [i.e., (widest width + perpendicular width + height)/3] over time for hydrangea and holly grown at the Middle Atlantic Coastal Plain $(\mathrm{n}=5)$ and Ridge and Valley $(\mathrm{n}=7)$ sites for 133 and 113 days, respectively. Vertical bars indicate SE.GR3

Table 3

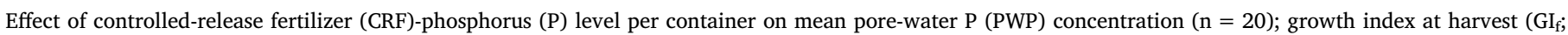

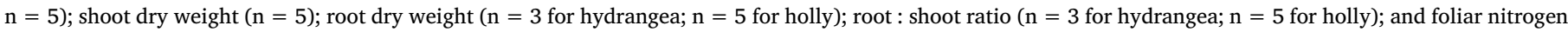
$(\mathrm{N}), \mathrm{P}$, and potassium $(\mathrm{K})$ concentrations $(\mathrm{n}=5)$ of hydrangea and holly grown at the Middle Atlantic Coastal Plain site (Virginia Beach, VA) for 130 days.

\begin{tabular}{|c|c|c|c|c|c|c|c|c|}
\hline \multirow[b]{2}{*}{ CRF-P (g) } & \multirow[b]{2}{*}{$\mathrm{PWP}^{\mathrm{z}}\left(\mathrm{mg} \mathrm{L}^{-1}\right)$} & \multirow[b]{2}{*}{$\underline{\mathrm{GI}_{\mathrm{f}}(\mathrm{cm})}$} & \multicolumn{2}{|c|}{ Dry wt $(\mathrm{g})$} & \multirow[b]{2}{*}{$\underline{\text { Root : shoot }}$} & \multicolumn{3}{|c|}{ Foliar nutrients ( $\mathrm{mg} \mathrm{g}^{-1}$ dry wt) } \\
\hline & & & $\underline{\text { Shoot }}$ & $\underline{\text { Root }}$ & & $\mathrm{N}$ & $\mathrm{P}$ & $\mathrm{K}$ \\
\hline & \multicolumn{8}{|c|}{ hydrangea } \\
\hline control & $2.2 \mathrm{a}^{\mathrm{y}}$ & $21.8 \mathrm{a}$ & $21.2 \mathrm{a}$ & 8.1 & $0.34 \mathrm{~b}$ & $3.23 \mathrm{a}$ & $0.34 \mathrm{a}$ & $1.83 \mathrm{ab}$ \\
\hline 0.1 & $0.1 \mathrm{~b}$ & $7.2 \mathrm{~b}$ & $5.1 \mathrm{~b}$ & 4.1 & $0.67 \mathrm{a}$ & $3.04 \mathrm{ab}$ & $0.14 \mathrm{~b}$ & $2.35 \mathrm{a}$ \\
\hline 0.2 & $0.3 \mathrm{~b}$ & $13.6 \mathrm{ab}$ & $9.4 \mathrm{~b}$ & 5.4 & $0.46 \mathrm{~b}$ & $2.75 \mathrm{abc}$ & $0.15 \mathrm{~b}$ & $1.89 \mathrm{ab}$ \\
\hline 0.3 & $0.8 \mathrm{a}$ & $17.5 \mathrm{a}$ & $15.0 \mathrm{ab}$ & 6.7 & $0.40 \mathrm{~b}$ & $2.59 \mathrm{bc}$ & $0.17 \mathrm{~b}$ & $1.67 \mathrm{~b}$ \\
\hline 0.4 & $1.1 \mathrm{a}$ & $17.5 \mathrm{a}$ & $14.1 \mathrm{ab}$ & 7.2 & $0.44 \mathrm{~b}$ & $2.29 \mathrm{c}$ & $0.19 \mathrm{~b}$ & $1.70 \mathrm{~b}$ \\
\hline \multicolumn{9}{|l|}{$P$-value } \\
\hline ANOVA & 0.0002 & 0.0015 & 0.0027 & 0.1441 & 0.0039 & 0.0019 & $<0.0001$ & 0.0272 \\
\hline $\mathrm{L}_{0.1-0.4^{\mathrm{x}}}$ & $<0.0001$ & 0.0019 & 0.0029 & 0.0328 & 0.0172 & 0.0002 & 0.0015 & 0.0054 \\
\hline \multirow[t]{2}{*}{$\mathrm{Q}_{0.1-0.4}$} & $<0.0001$ & 0.0030 & 0.0066 & 0.1048 & 0.0049 & 0.0014 & 0.0064 & 0.0065 \\
\hline & \multicolumn{8}{|c|}{ holly } \\
\hline control & $3.9 \mathrm{a}$ & $16.8 \mathrm{~b}$ & $11.2 \mathrm{~b}$ & $3.3 \mathrm{~b}$ & $0.29 \mathrm{~b}$ & $2.40 \mathrm{a}$ & $0.24 \mathrm{a}$ & $1.38 \mathrm{a}$ \\
\hline 0.1 & $0.3 \mathrm{c}$ & $6.9 \mathrm{c}$ & $4.7 \mathrm{c}$ & $4.3 \mathrm{ab}$ & $0.92 \mathrm{a}$ & $1.64 \mathrm{c}$ & $0.08 \mathrm{c}$ & $0.98 \mathrm{c}$ \\
\hline 0.2 & $1.0 \mathrm{bc}$ & $15.1 \mathrm{~b}$ & $11.1 \mathrm{~b}$ & $6.1 \mathrm{a}$ & $0.63 \mathrm{ab}$ & $1.97 \mathrm{bc}$ & $0.15 \mathrm{~b}$ & $1.07 \mathrm{bc}$ \\
\hline 0.3 & $1.1 \mathrm{bc}$ & $16.9 \mathrm{~b}$ & $11.5 \mathrm{~b}$ & $4.9 \mathrm{ab}$ & $0.43 \mathrm{~b}$ & $2.08 \mathrm{ab}$ & $0.18 \mathrm{~b}$ & $1.19 \mathrm{~b}$ \\
\hline 0.4 & $2.6 \mathrm{ab}$ & $23.3 \mathrm{a}$ & $17.6 \mathrm{a}$ & $5.7 \mathrm{ab}$ & $0.33 \mathrm{~b}$ & $1.94 \mathrm{bc}$ & $0.20 \mathrm{ab}$ & $1.23 \mathrm{ab}$ \\
\hline \multicolumn{9}{|l|}{$P$-value } \\
\hline ANOVA & $<0.0001$ & $<0.0001$ & $<0.0001$ & 0.0238 & 0.0002 & $<0.0001$ & $<0.0001$ & $<0.0001$ \\
\hline $\mathrm{L}_{0.1-0.4}$ & $<0.0001$ & $<0.0001$ & $<0.0001$ & 0.3168 & 0.0001 & 0.0156 & $<0.0001$ & $<0.0001$ \\
\hline$Q_{0.1-0.4}$ & $<0.0001$ & $<0.0001$ & $<0.0001$ & 0.4658 & 0.0005 & 0.0006 & $<0.0001$ & 0.0003 \\
\hline
\end{tabular}

${ }^{\mathrm{z}}$ Pore-water P data were pooled over time then log transformed to meet the constant variance assumption. After ANOVA (and means separation) and linear and quadratic regression P-values were attained, mean PWP levels were converted back to original measured values.

y Letters within columns separate means by Tukey's Honest Significant Difference at $\mathrm{P} \leq 0.05$.

$\mathrm{x}$ Only the experimental fertilizers were included in linear and quadratic regression analysis. 
applied). The apparent discrepancy between these two studies is most likely due to differing nutrient supply methods, solution vs. CRF, and the resulting PWP concentrations and amounts related to those nutrient application methods; hence a comparison of these findings is difficult to interpret. When growing containerized Spiraea $\times$ bumalda Burven 'Gold Mound', Clark and Zheng (2017) showed that the top-dress CRF rate that produced highest quality plants ( $4.5 \mathrm{~g}$ CRF-N per 7.6 L container) had pour-through $\mathrm{P}$ concentrations consistently less than $\approx 3 \mathrm{mg} \mathrm{L}^{-1} \mathrm{P}$. Groves et al. (1998a, b) reported similar findings for container-grown Cotoneaster dammeri 'Skogholm' fertilized with substrate-incorporated CRF. Interestingly, $\mathrm{GI}_{\mathrm{f}}$ and SDW values of holly fertilized with $0.4 \mathrm{~g}$ CRF-P were higher than those of the control, despite the $50 \%$ higher $\mathrm{P}$ content in the control CRF. As previously discussed, higher $\mathrm{GI}_{\mathrm{f}}$ and SDW of holly given $0.4 \mathrm{~g}$ P compared to the control CRF could be a consequence of the delayed nutrient release of the control CRF as indicated by consistently lower pore-water EC values (Fig. 2) and, prior to 88 DAI, PWP concentrations (Table 2).

Hydrangea RDW (Table 3) increased linearly as applied P increased from 0.1 to $0.4 \mathrm{~g}$; however, RDW of those fertilized with the control CRF was the same as in those given 0.1 to $0.4 \mathrm{~g}$ CRF-P. Reduced RDW in response to low-P fertility has been reported in Hydrangea paniculata 'Limelight' (Shreckhise et al., 2018), Eucalyptus dunnii Maiden and Corymbia citriodora (Hook.) K.D. Hill \& L.A.S. Johnson (Niu et al., 2015). Root dry weight of holly was the same across all four experimental CRF treatments and was lower in plants given the control than in those that received $0.2 \mathrm{~g}$ P. Studies that have reported the effect of $\mathrm{P}$ fertilizer levels on RDW of Ilex crenata 'Helleri' are inconsistent. In agreement with our findings, Shreckhise et al. (2018) observed no differences in RDW of Ilex crenata 'Helleri' across fertilizer treatments containing 0.5 to $6 \mathrm{mg} \mathrm{L}^{-1} \mathrm{P}$. Yeager and Wright also (Yeager and Wright, 1982a; and 1982b) reported no differences in Ilex crenata 'Helleri' RDW in one experiment in which fertilizer-P was increased in $5 \mathrm{mg} \mathrm{L}^{-1}$ increments from 0 to $20 \mathrm{mg} \mathrm{L}^{-1}$; however, RDW decreased in a subsequent experiment in which $\mathrm{P}$ was incrementally increased from 0 to $30 \mathrm{mg} \mathrm{L}^{-1}$.

Root : shoot ratio of hydrangea and holly (Table 3) decreased quadratically and linearly, respectively, with increasing experimental CRF-P rate. Root : shoot ratio values of hydrangea and holly fertilized with the control were the same as in those given 0.2 to $0.4 \mathrm{gP}$. Increased root : shoot ratio values in response to growth-limiting P levels suggest that as P fertility shifts from growth-limiting to sufficient, shoot growth is preferentially stimulated over root growth. This negative relationship between fertilizer-P and root : shoot ratio has been reported in several nursery and greenhouse taxa [e.g., Betula alnoides Buch.-Ham. ex D. Don (Chen et al., 2010), Betula pendula Roth. (Ericsson and Ingestad, 1988) and Lantana camara L 'New Gold' (Kim and Li, 2016)].

\subsubsection{Foliar nutrient concentrations}

Hydrangea foliar P concentrations (Table 3 ) increased linearly with increasing experimental CRF-P rate, and foliar P concentrations of the control plants were higher than in plants that received an experimental CRF. Luxury consumption of $P$ was evident in hydrangea since SDW and $\mathrm{GI}_{\mathrm{f}}$ values were unchanged as foliar $\mathrm{P}$ concentrations increased from 0.19 to $0.34 \mathrm{mg} \mathrm{g}^{-1}$ dry weight (DW). Luxury P consumption has been reported for numerous woody and herbaceous plant taxa (e.g., Dickey et al., 1967; Havis and Baker, 1985; Kraus et al., 2011; Kim and Li, 2016; Ristvey et al., 2007; Yeager and Wright, 1982b). Hydrangea foliar $\mathrm{P}$ concentrations associated with maximal $\mathrm{GI}_{\mathrm{f}}$ and $\mathrm{SDW}$ values were in the range of 0.17 to $0.34 \mathrm{mg} \mathrm{g}^{-1} \mathrm{DW}$. This observed foliar P sufficiency range is below that reported by Bryson et al. (2014) for Hydrangea macrophylla ( 0.23 to $0.67 \mathrm{mg} \mathrm{g}^{-1} \mathrm{DW}$ ); however, optimal foliar nutrient ranges are known to be cultivar-dependent (Sonneveld and Voogt, 2009). Furthermore, foliar nutrient sufficiency ranges reported by Bryson et al. (2014) are based on survey data and therefore may not indicate actual threshold nutrient levels associated with maximal growth. The $400 \%$ increase in experimental CRF-P ( 0.1 to $0.4 \mathrm{~g} \mathrm{P}$ ) resulted in a respective $36 \%$ increase in hydrangea foliar $\mathrm{P}$; however, the relatively minor increase in CRF-P from 0.4 to $0.6 \mathrm{~g} \mathrm{P}$ (50\% increase in CRF-P) resulted in a $0.79 \%$ increase in foliar $P$. The reason the increase in CRF-P from 0.4 to $0.6 \mathrm{~g}$ (control) for hydrangea resulted in a disproportional increase in tissue $P$ concentration cannot be ascertained from data collected in this study. However, the authors speculate that in addition to $\mathrm{P}$, concentrations of other nutrients and nutrient ions in pore-water throughout the study may have differed for the control CRF compared to the experimental CRFs, as indicated by EC data (Fig. 2). Consequently, the presence and extent of possible mineral nutrient synergistic effects on $\mathrm{P}$ uptake (e.g., $\mathrm{NO}_{3}{ }^{-}$to $\mathrm{NH}_{4}{ }^{+}$ratio; Jiménez et al., 2007) may have been different for the control CRF compared to the experimental CRFs. Holly foliar P increased quadratically with increasing CRF-P level within experimental CRFs. According to Bryson et al. (2014) and Shreckhise et al. (2018), Ilex crenata 'Helleri' tissue P concentrations of 0.08 to $0.11 \mathrm{mg} \mathrm{g}^{-1} \mathrm{DW}$ and 0.10 to $0.22 \mathrm{mg} \mathrm{g}^{-1} \mathrm{DW}$, respectively, indicate $P$ sufficiency. In our study, tissue $P$ concentrations of 0.08 to $0.18 \mathrm{mg} \mathrm{g}^{-1} \mathrm{DW}$ (i.e., 0.1 to $0.4 \mathrm{~g}$ CRF-P treatments) corresponded with submaximal SDW, suggesting the critical tissue-P concentration for holly is $>0.18 \mathrm{mg} \mathrm{g}^{-1}$ DW when grown in climactic conditions observed in this study. However, further research is needed to better understand this discrepancy. Despite having 36\% less SDW, holly fertilized with the control CRF had equivalent foliar P concentrations to those given $0.4 \mathrm{~g}$ P. Bi et al. (2007) reported that biomass of two Rhododendron taxa increased two to four weeks after tissue-N accumulation in response to $\mathrm{N}$ fertilization. Thus, a possible explanation for the relatively high tissue $\mathrm{P}$ concentrations of holly fertilized with the control CRF is that the delayed P release of the control CRF may have enabled plants to take up and translocate $\mathrm{P}$ to leaves and growing tips, but tissue samples were harvested prior to shoot growth response to increased $\mathrm{P}$ availability.

In response to increasing CRF-P from 0.1 to $0.4 \mathrm{~g}$, foliar $\mathrm{N}$ concentrations (Table 3 ) decreased linearly in hydrangea but increased quadratically in holly. The decrease in foliar $\mathrm{N}$ of hydrangea with increasing CRF-P treatment is likely a dilution effect due to greater leaf size of plants that received higher CRF-P rates. The dilution effect is the dilution or concentration of a nutrient in plant tissue relative to the level of biomass accumulated (Jarrell and Beverly, 1981). Although leaf area was not measured in this study, hydrangea leaves were noted as being smaller in plants fertilized with $0.1 \mathrm{~g}$ P compared to all other CRF$\mathrm{P}$ rates. Relatively low $\mathrm{N}$ concentrations of holly fertilized with $0.1 \mathrm{~g} \mathrm{P}$ is likely a reflection of the phenotypic stage of the tissue sampled. Gilliam and Wright (1978) showed that nutrient-limited Ilex crenata 'Helleri', a taxon with episodic shoot growth, required more time to complete a growth flush than those with an ample nutrient supply. In the current study, holly fertilized with $0.1 \mathrm{~g}$ P contained no newly expanded shoots at the time of tissue harvest, whereas tissue samples of holly fertilized with 0.2 to $0.4 \mathrm{~g} \mathrm{P}$ or the control CRF were taken from expanding or recently expanded shoot tips. Since plant tissue N concentration tends to decrease with tissue age (Marschner, 2012), the mature shoot tips of holly given $0.1 \mathrm{~g}$ CRF-P had less $\mathrm{N}$ than the relatively young shoot tips harvested from all other treatments. Thus, caution should be used when interpreting nutrient levels of stem tip samples, particularly when taken from taxa that have multiple growth flushes within a growing season. Shreckhise et al. (2018), who used the same method employed in this study for obtaining holly tissue samples, also observed increasing tissue $\mathrm{N}$ of Ilex crenata 'Helleri' as P-fertilizer increased from 0.5 to $6.0 \mathrm{mg} \mathrm{L}^{-1} \mathrm{P}$. Control plants achieved similar foliar $\mathrm{N}$ levels as those fertilized with 0.1 to $0.2 \mathrm{gP}$ in hydrangea and $0.3 \mathrm{gP}$ in holly.

In response to increasing CRF-P supply from 0.1 to $0.4 \mathrm{~g}$, foliar $\mathrm{K}$ concentrations (Table 3) for hydrangea and holly followed the same decreasing and increasing trends, respectively, as observed for foliar $\mathrm{N}$ concentration. Foliar $\mathrm{K}$ levels of hydrangea fertilized with the control CRF were the same as in those that received an experimental CRF. Holly 
Table 4

Effect of sampling date [days after experiment initiation (DAI)] and controlledrelease fertilizer (CRF)-phosphorus (P) level within each sampling date on pourthrough-extracted pore-water $P$ concentration $(n=4)$ of hydrangea and holly grown at the Ridge and Valley site (Blacksburg, VA).

Pore-water P conc. (mg L $\left.{ }^{-1}\right)$

\begin{tabular}{|c|c|c|c|c|c|c|c|}
\hline CRF-P (g) & 19 DAI & 36 DAI & $61 \mathrm{DAI}$ & 91 DAI & $110 \mathrm{DAI}$ & $P$-value ${ }^{\mathrm{x}}$ & HSD \\
\hline \multicolumn{8}{|c|}{ hydrangea } \\
\hline control & 3.67 & $1.20 \mathrm{~b}^{\mathrm{z}}$ & 2.78 & $5.20 \mathrm{a}$ & 1.08 & 0.0039 & 3.05 \\
\hline 0.1 & 1.32 & $0.44 \mathrm{~b}$ & 0.28 & $0.62 \mathrm{~b}$ & 0.13 & 0.6836 & - \\
\hline 0.2 & 4.17 & $2.16 \mathrm{ab}$ & 3.33 & $1.07 \mathrm{ab}$ & 0.42 & 0.6253 & - \\
\hline 0.3 & 2.78 & $2.89 \mathrm{ab}$ & 5.58 & $3.39 \mathrm{ab}$ & 1.06 & 0.5168 & - \\
\hline 0.4 & 2.26 & $5.23 \mathrm{a}$ & 7.12 & $2.76 \mathrm{ab}$ & 1.34 & 0.2993 & - \\
\hline \multicolumn{8}{|l|}{$P$-value } \\
\hline ANOVA & 0.8293 & 0.0194 & 0.3922 & 0.0253 & 0.3236 & & \\
\hline $\mathrm{L}_{0.1-0.4^{\mathrm{y}}}$ & 0.8752 & 0.0033 & 0.0706 & 0.0288 & 0.0531 & & \\
\hline$Q_{0.1-0.4}$ & 0.7056 & 0.0152 & 0.1996 & 0.0812 & 0.1655 & & \\
\hline \multicolumn{8}{|c|}{ holly } \\
\hline control & $2.91 \mathrm{ab}$ & $0.74 \mathrm{~b}$ & 1.39 & $2.65 \mathrm{ab}$ & $6.52 \mathrm{ab}$ & 0.1239 & - \\
\hline 0.1 & $2.08 \mathrm{ab}$ & $0.16 \mathrm{~b}$ & 0.08 & $0.15 \mathrm{~b}$ & $0.10 \mathrm{~b}$ & $<0.0001$ & 0.59 \\
\hline 0.2 & $1.76 \mathrm{~b}$ & $0.70 \mathrm{~b}$ & 0.64 & $1.45 \mathrm{ab}$ & $1.50 \mathrm{ab}$ & 0.3139 & - \\
\hline 0.3 & $2.34 \mathrm{ab}$ & $1.62 \mathrm{ab}$ & 1.28 & $1.55 \mathrm{ab}$ & $2.97 \mathrm{ab}$ & 0.1979 & - \\
\hline 0.4 & $3.27 \mathrm{a}$ & $4.01 \mathrm{a}$ & 5.07 & $5.41 \mathrm{a}$ & $7.64 \mathrm{a}$ & 0.4910 & - \\
\hline \multicolumn{8}{|l|}{$P$-value } \\
\hline ANOVA & 0.0385 & 0.0160 & 0.0714 & 0.0276 & 0.0259 & & \\
\hline $\mathrm{L}_{0.1-0.4}$ & 0.0236 & 0.0036 & 0.0162 & 0.0075 & $<0.0001$ & & \\
\hline$Q_{0.1-0.4}$ & 0.0189 & 0.0090 & 0.0288 & 0.0175 & $<0.0001$ & & \\
\hline
\end{tabular}

${ }^{\mathrm{z}}$ Letters within columns separate means by Tukey's Honest Significant Difference at $\mathrm{P} \leq 0.05$ (control not included).

y Only the experimental fertilizers were included in linear and quadratic regression analysis.

${ }^{x}$ P-values were attained via ANOVA to assess the changes in PWP concentrations over time within CRF treatments. Tukey's Honest Significant Difference (HSD) value is provided for means comparisons within rows.

fertilized with the control CRF had higher foliar $\mathrm{K}$ levels than in all other treatments except $0.4 \mathrm{~g}$ P. Similar to tissue N, the dilution effect and tissue age may explain the decreasing $\mathrm{K}$ levels with increasing CRF$\mathrm{P}$ for hydrangea and holly, respectively.

\subsection{4. $p H$}

Fertilizer-P treatment did not affect substrate $\mathrm{pH}(\mathrm{P}>0.05)$; thus, values were pooled across fertilizer treatments within each taxon. Hydrangea substrate $\mathrm{pH}$ values increased from 5.3 at $1 \mathrm{DAI}$ to 6.2 at 16 DAI, then stayed between 6.2 and 6.5 for the remainder of the study. Substrate $\mathrm{pH}$ values for holly increased from 5.1 at 1 DAI to 6.2 at 28 DAI; thereafter, $\mathrm{pH}$ values stayed the same until $114 \mathrm{DAI}$, at which $\mathrm{pH}$ was 6.5. The increase in substrate $\mathrm{pH}$ in the first 16 to 28 days was most likely a result of dolomite dissolution and subsequent decrease in hydrogen ion $\left(\mathrm{H}^{+}\right)$concentration as $\mathrm{H}^{+}$reacted with hydroxide products to form water. Hydrangea $\mathrm{pH}$ values were 0.4 units higher than those of holly at 16 and $88 \mathrm{DAI}$; however, since $\mathrm{pH}$ values were the same across taxa at all other sampling dates, the 0.4 -unit $\mathrm{pH}$ difference at 16 and 88 DAI has minor horticultural importance.

\subsection{Ridge and valley site}

\subsubsection{Pore-water phosphorus}

At 36 and 91 DAI, hydrangea PWP concentrations (Table 4) increased linearly with increasing $P$ in experimental CRF treatments. Pore-water P concentrations for holly increased linearly with increasing $P$ in experimental CRFs at all sampling dates except 19 DAI in which PWP concentrations responded quadratically. Absence of a treatment effect on PWP concentrations at 61 DAI for hydrangea was due to unusually high variance in measured $\mathrm{P}$ concentrations across replications for the $0.2,0.3$ and $0.4 \mathrm{gP}$ rates (SE $= \pm 2.3,3.0$ and $4.1 \mathrm{mg} \mathrm{L}^{-1}$ $\mathrm{P}$, respectively). With the exception of hydrangea at 91 DAI, PWP concentrations within each sampling date of plants fertilized with the control CRF were repeatedly the same as those given $0.1 \mathrm{~g} \mathrm{P}$ for both taxa. Additionally, for hydrangea fertilized with the control CRF, PWP concentrations peaked at 91 DAI, whereas PWP of the experimental CRFs were constant over time. Parallel to results observed for the MACP site, these data suggest that the P release pattern of the control CRF was inconsistent with that of the experimental CRFs. Holly fertilized with $0.1 \mathrm{gP}$ had higher PWP levels at $19 \mathrm{DAI}$ than at any other sampling date, indicating PWP concentrations may have been diminished by root uptake after root establishment.

\subsubsection{Growth index and carbon allocation}

Hydrangea GI (Fig. 3) increased quadratically with increasing P in experimental $\mathrm{CRFs}$ at $60(\mathrm{~F}=4.55 ; \mathrm{P}=0.0207), 90 \quad(\mathrm{~F}=25.5$; $\mathrm{P}<0.0001)$ and $109 \mathrm{DAI}(\mathrm{F}=37.4 ; \mathrm{P}<0.0001)$. Although GI values of hydrangea fertilized with 0.2 to 0.4 or the control CRF were consistently the same, by $90 \mathrm{DAI}$, GI values of plants given $0.1 \mathrm{~g} \mathrm{P}$ were $64 \%$ less than those of plants in any other treatment. From 19 to 90 DAI, the average PWP concentrations for hydrangea fertilized with 0.1 and $0.2 \mathrm{~g}$ P were $0.7 \pm 0.32 \mathrm{SE}$ and $2.7 \pm 1.00 \mathrm{sE} \mathrm{mg} \cdot \mathrm{L}^{-1}$, respectively; thus, the critical PWP concentration for hydrangea is most likely between 0.7 and $2.7 \mathrm{mg} \mathrm{L}^{-1}$. Growth index values of holly fertilized with 0.1 to $0.4 \mathrm{~g}$ P were the same at all measurement dates, suggesting mean PWP concentrations between 0.5 and $5.1 \mathrm{mg} \mathrm{L}^{-1}$ were adequate for maximal shoot growth. Relative to holly in the control CRF treatment, GI values of plants fertilized with $0.2 \mathrm{~g}$ P were $530 \%$ higher at $60 \mathrm{DAI}$ and $\approx 108 \%$ higher at 90 and 109 DAI. Despite having submaximal GI, holly given the control CRF had mean PWP concentrations within the adequate range according to PWP data from those fertilized with experimental CRFs (Table 5). Since control CRF PWP values of holly were constant over time and the same as in plants fertilized with 0.3 or $0.4 \mathrm{~g} \mathrm{P}$, P was not likely limiting for holly given the control CRF. At 19, 36 and 61 DAI, EC values (Fig. 2) of holly fertilized with the control CRF were $42 \%$ to $65 \%$ lower than those of all other treatments $(\mathrm{P}<0.01)$, indicating $\mathrm{N}$ or $\mathrm{K}^{+}$or both may have been initially limiting growth.

Shoot dry weight and $\mathrm{GI}_{\mathrm{f}}$ had a strong, positive correlation in both taxa ( $r=0.87$ for hydrangea; $r=0.80$ for holly). Consistent with results observed at the MACP site, hydrangea $\mathrm{GI}_{\mathrm{f}}$ and SDW (Table 5) increased quadratically with increasing experimental CRF-P and was highest in plants fertilized with the control CRF or 0.3 to $0.4 \mathrm{~g} \mathrm{P}$. Hydrangea growth response pattern to increasing experimental CRF-P rate mimics the curvilinear response of mean PWP concentrations (Table 5) to CRF-P rate, suggesting $P$ is the primary variable influencing growth differences between experimental CRF treatments. Maximal $\mathrm{GI}_{\mathrm{f}}$ and SDW of holly was observed in plants fertilized with 0.2 to $0.4 \mathrm{~g}$ P. The reason holly seemingly required a higher CRF-P rate at the MACP site than at the RV site is unclear and may be related to environmental differences between ecoregions. Shoot dry weight and $\mathrm{GI}_{\mathrm{f}}$ values of holly given the control CRF were about half that of plants fertilized with $0.4 \mathrm{~g} \mathrm{P}$. As previously discussed, relatively low $\mathrm{GI}_{\mathrm{f}}$ and $\mathrm{SDW}$ values of holly fertilized with the control CRF is likely a consequence of delayed $\mathrm{N}$ and $\mathrm{K}^{+}$release from the CRF as indicated by low EC values (Fig. 2).

Hydrangea and holly RDW (Table 5) response to increasing CRF-P was similar to that of respective $\mathrm{GI}_{\mathrm{f}}$ values. Root dry weight of hydrangea increased quadratically with increasing experimental CRF-P and was highest in those fertilized with 0.2 to $0.4 \mathrm{gP}$ or the control CRF. Root dry weight of holly was the same across experimental CRFs, all of which had higher RDW than the control, except for those given $0.3 \mathrm{~g}$ P. Root dry weight results for both taxa grown at the RV site generally correspond with results observed at the MACP site. Root : shoot ratio values of both taxa declined quadratically with increasing $P$ among experimental CRFs. Root : shoot values of hydrangea given the control CRF were the same as those fertilized with 0.2 to $0.4 \mathrm{~g} \mathrm{P}$, and in holly, root : shoot values of those given the control CRF were the same as those of all other treatments. In hydrangea, CRF-P rate had the greatest effect on root : shoot values as P levels shifted from shoot and 
Table 5

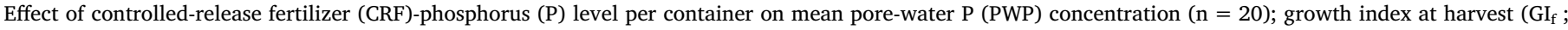

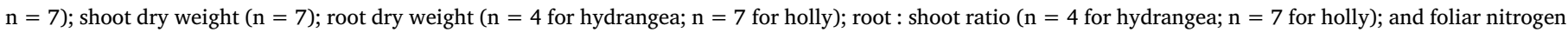
$(\mathrm{N})$, P, and potassium (K) concentrations $(\mathrm{n}=7)$ of hydrangea and holly grown at Ridge and Valley site (Blacksburg, VA) for 109 days.

\begin{tabular}{|c|c|c|c|c|c|c|c|c|}
\hline \multirow[b]{2}{*}{$\begin{array}{l}\text { CRF-P } \\
\text { (g) }\end{array}$} & \multirow[b]{2}{*}{$\mathrm{PWP}^{\mathrm{Z}}\left(\mathrm{mg} \mathrm{L}^{-1}\right)$} & \multirow[b]{2}{*}{$\begin{array}{c}\underline{\mathrm{GI}_{\mathrm{f}}} \\
\underline{(\mathrm{cm})}\end{array}$} & \multicolumn{2}{|l|}{ Dry wt $(\mathrm{g})$} & \multirow[b]{2}{*}{$\underline{\text { Root : shoot }}$} & \multicolumn{3}{|c|}{ Foliar nutrients (mg.g ${ }^{-1}$ dry wt) } \\
\hline & & & $\underline{\text { Shoot }}$ & $\underline{\text { Root }}$ & & $\mathrm{N}$ & $\mathrm{P}$ & $\mathrm{K}$ \\
\hline & \multicolumn{8}{|c|}{ hydrangea } \\
\hline control & $2.8 \mathrm{a}^{\mathrm{y}}$ & $18.2 \mathrm{a}$ & $30.3 \mathrm{ab}$ & $7.49 \mathrm{ab}$ & $0.27 \mathrm{~b}$ & $2.46 \mathrm{~b}$ & $0.20 \mathrm{a}$ & $1.42 \mathrm{~b}$ \\
\hline 0.1 & $0.6 \mathrm{~b}$ & $05.6 \mathrm{~b}$ & $10.9 \mathrm{c}$ & $5.09 \mathrm{~b}$ & $0.47 \mathrm{a}$ & $3.33 \mathrm{a}$ & $0.09 \mathrm{~d}$ & $1.95 \mathrm{a}$ \\
\hline 0.2 & $2.2 \mathrm{ab}$ & $17.5 \mathrm{a}$ & $26.2 \mathrm{~b}$ & $7.31 \mathrm{ab}$ & $0.28 \mathrm{~b}$ & $2.68 \mathrm{~b}$ & $0.12 \mathrm{c}$ & $1.51 \mathrm{~b}$ \\
\hline 0.3 & $3.1 \mathrm{a}$ & $18.4 \mathrm{a}$ & $34.0 \mathrm{ab}$ & $8.81 \mathrm{a}$ & $0.27 \mathrm{~b}$ & $2.52 \mathrm{~b}$ & $0.11 \mathrm{~cd}$ & $1.26 \mathrm{~b}$ \\
\hline 0.4 & 3.7 a & $18.8 \mathrm{a}$ & $35.9 \mathrm{a}$ & $9.39 \mathrm{a}$ & $0.25 \mathrm{~b}$ & $2.60 \mathrm{~b}$ & $0.16 \mathrm{~b}$ & $1.25 \mathrm{~b}$ \\
\hline \multicolumn{9}{|l|}{$P$-value } \\
\hline ANOVA & $<0.0001$ & $<0.0001$ & $<0.0001$ & 0.0206 & 0.0002 & $<0.0001$ & $<0.0001$ & $<0.0001$ \\
\hline $\mathrm{L}_{0.1-0.4^{\mathrm{x}}}$ & $<0.0001$ & $<0.0001$ & $<0.0001$ & 0.0013 & 0.0010 & $<0.0001$ & $<0.0001$ & $<0.0001$ \\
\hline \multirow[t]{2}{*}{$Q_{0.1-0.4}$} & $<0.0001$ & $<0.0001$ & $<0.0001$ & 0.0040 & 0.0002 & $<0.0001$ & $<0.0001$ & $<0.0001$ \\
\hline & \multicolumn{8}{|c|}{ holly } \\
\hline control & $2.8 \mathrm{ab}$ & $6.8 \mathrm{~b}$ & $10.6 \mathrm{~b}$ & $3.57 \mathrm{~b}$ & 0.36 & $2.36 \mathrm{a}$ & $0.20 \mathrm{a}$ & $1.17 \mathrm{a}$ \\
\hline 0.1 & $0.5 \mathrm{c}$ & $8.2 \mathrm{ab}$ & $12.2 \mathrm{~b}$ & $5.10 \mathrm{a}$ & 0.42 & $1.75 \mathrm{c}$ & $0.09 \mathrm{c}$ & $0.96 \mathrm{~b}$ \\
\hline 0.2 & $1.2 \mathrm{~b}$ & $13.8 \mathrm{a}$ & $17.5 \mathrm{a}$ & $5.83 \mathrm{a}$ & 0.34 & $1.90 \mathrm{bc}$ & $0.13 \mathrm{~b}$ & $0.92 \mathrm{~b}$ \\
\hline 0.3 & $1.9 \mathrm{~b}$ & $11.5 \mathrm{ab}$ & $13.0 \mathrm{ab}$ & $4.65 a b$ & 0.37 & $2.04 \mathrm{~b}$ & $0.14 \mathrm{~b}$ & $1.01 \mathrm{ab}$ \\
\hline 0.4 & $5.1 \mathrm{a}$ & $13.1 \mathrm{a}$ & $15.5 a b$ & $4.96 \mathrm{a}$ & 0.32 & $1.98 \mathrm{bc}$ & $0.17 \mathrm{~b}$ & $1.05 \mathrm{ab}$ \\
\hline \multicolumn{9}{|l|}{$P$-value } \\
\hline ANOVA & $<0.0001$ & 0.0048 & 0.0027 & 0.0006 & 0.0797 & $<0.0001$ & $<0.0001$ & 0.0031 \\
\hline $\mathrm{L}_{0.1-0.4}$ & $<0.0001$ & 0.0925 & 0.3916 & 0.3151 & 0.0109 & 0.0040 & $<0.0001$ & 0.0233 \\
\hline$Q_{0.1-0.4}$ & $<0.0001$ & 0.1155 & 0.4245 & 0.5159 & 0.0310 & 0.0036 & $<0.0001$ & 0.0382 \\
\hline
\end{tabular}

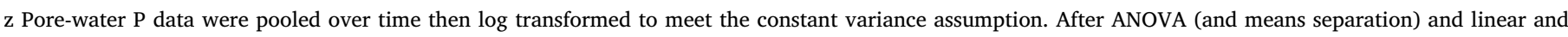
quadratic regression P-values were attained, mean PWP levels were converted back to original measured values.

y Letters within columns separate means by Tukey's Honest Significant Difference at $\mathrm{P} \leq 0.05$.

$\mathrm{x}$ Only the experimental fertilizers were included in linear and quadratic regression analysis.

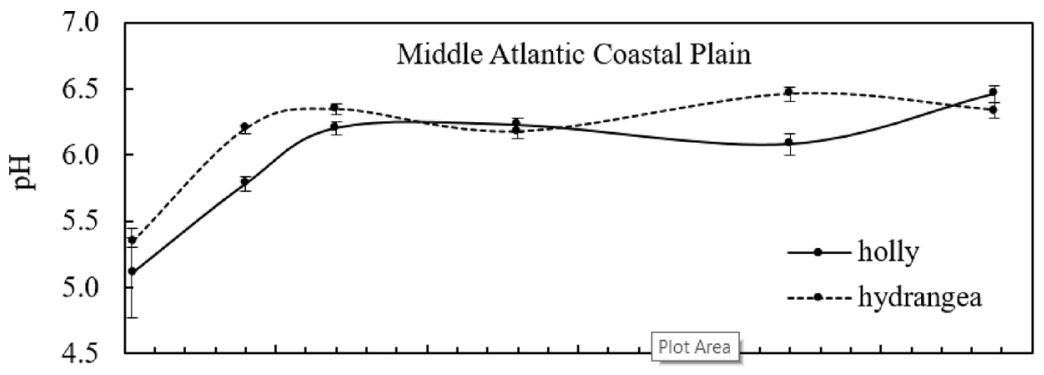

Fig. 4. Substrate pore-water $\mathrm{pH}$ of hydrangea and holly grown at the Middle Atlantic Coastal Plain and Ridge and Valley sites for 133 and 113 days, respectively. Values were pooled across controlled-release fertilizer treatments at each sampling date $(n=20)$ since treatment did not affect $\mathrm{pH}(\mathrm{P}<0.05)$. Vertical bars indicate SE.GR 4

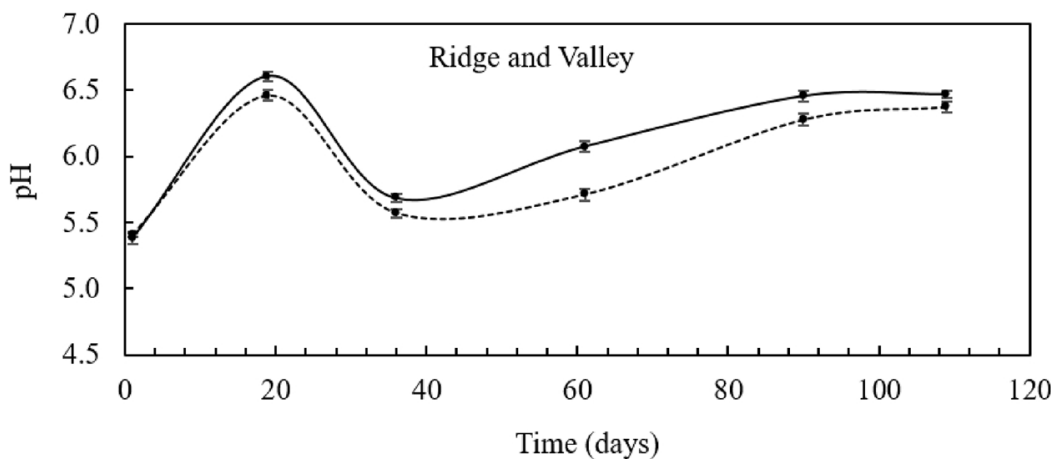

root growth-limiting $(0.1 \mathrm{gP})$ to sufficient $(\geq 0.2 \mathrm{gP}$ ). This finding supports results observed at the MACP site in that P deficiency had a greater effect on shoot growth than root growth.

\subsubsection{Foliar nutrient concentrations}

Foliar P concentrations (Table 5) in both taxa increased linearly with increasing experimental CRF-P rate. Although the control CRF resulted in highest tissue-P concentrations in hydrangea, tissue-P concentrations as low as $0.11 \mathrm{mg} \mathrm{g}^{-1} \mathrm{DW}(0.3 \mathrm{~g}$ CRF-P) were sufficient for maximal SDW which indicates luxury consumption of $\mathrm{P}$ by hydrangea given $0.4 \mathrm{gP}$ or the control CRF. The tissue-P concentration of P-deficient hydrangea (i.e., those given $0.1 \mathrm{~g} \mathrm{P}$ ) was $0.09 \mathrm{mg} \mathrm{g}^{-1} \mathrm{DW}$, suggesting the critical tissue-P concentration is between 0.09 and $0.11 \mathrm{mg} \mathrm{g}^{-1} \mathrm{DW}$. Similar to hydrangea, highest foliar P levels in holly were observed in those fertilized with the control CRF; however, unlike in hydrangea, relatively high foliar-P concentrations did not coincide with maximal SDW. As previously discussed, P limitation was not likely the cause of relatively low SDW and $\mathrm{GI}_{\mathrm{f}}$ values of holly fertilized with the control CRF. Relatively low EC values prior to 91 DAI for holly given the control CRF indicate other nutrients in the CRF (e.g., $\mathrm{N}$ and 
$\mathrm{K}^{+}$) may have been initially growth-limiting.

Foliar $\mathrm{N}$ and $\mathrm{K}$ (Table 5) decreased quadratically in hydrangea with increasing $\mathrm{P}$ in experimental fertilizer. Foliar $\mathrm{N}$ and $\mathrm{K}$ levels in hydrangea fertilized with the control CRF were the same as in those fertilized with 0.2 to $0.4 \mathrm{~g} \mathrm{P}$. Although P fertilizer level had a moderately strong negative correlation with foliar $\mathrm{N}(\mathrm{r}=-0.64)$ in hydrangea, the negative correlation between SDW and foliar $\mathrm{N}$ was stronger $(\mathrm{r}=-0.80)$. Accordingly, SDW likely had a greater effect on foliar $\mathrm{N}$ levels than did CRF-P treatments. The negative relationship between SDW and foliar $\mathrm{N}$ level can be explained by the dilution effect as noted for the MACP site. In holly, foliar N and $\mathrm{K}$ increased quadratically and linearly, respectively, with increasing $\mathrm{P}$. Foliar $\mathrm{N}$ levels in holly fertilized with the control CRF were higher than those in all other treatments, whereas foliar $\mathrm{K}$ levels in plants given the control CRF were similar to in those given 0.3 to $0.4 \mathrm{~g} \mathrm{P}$.

\subsection{4. $p H$}

Controlled-release fertilizer-P treatment did not affect substrate $\mathrm{pH}$ $(\mathrm{P}<0.05)$; thus, values were pooled across fertilizer treatments within each taxon. In both taxa, substrate $\mathrm{pH}$ (Fig. 4) increased from $\approx 5.4$ to $\approx 6.5$ in the first 19 days after potting, then decreased to $\approx 5.6$ between 19 and 36 DAI. After 36 DAI and for the remainder of the study, $\mathrm{pH}$ of both taxa increased to a final value of $\approx 6.5$. As previously discussed for the MACP site, reactions following dolomite dissolution likely caused the increase in substrate $\mathrm{pH}$ between days 1 and 19. The decrease in $\mathrm{pH}$ of both taxa between 19 and 36 DAI may have been caused by plant, microbial, fertilizer and/or other related factors.

\section{Conclusions}

Hydrangea $\mathrm{GI}_{\mathrm{f}}$ and SDW results were consistent across experiment sites, indicating that CRFs containing $1.3 \%$ to $2.6 \% \mathrm{P}\left(3 \%\right.$ to $\left.6 \% \mathrm{P}_{2} \mathrm{O}_{5}\right)$, applied at a rate of 0.3 to $0.6 \mathrm{~g} \mathrm{P}$ per 3.8-L container, are sufficient for maximal growth. Accordingly, compared to the $\mathrm{P}$ content in conventional CRF formulations for container-grown nursery crops (i.e., $2.6 \%$ P), CRF-P for hydrangea fertilization may be reduced by $50 \%$ without affecting plant growth. Given that hydrangea is the second leading deciduous shrub produced in the U.S. (USDA, 2014), a 50\% reduction in $\mathrm{P}$ fertilization for Hydrangea macrophylla could have major implications for reducing P runoff from container-nursery sites. However, since P requirements are often cultivar-specific, growers should experiment with using low-P CRFs on the cultivars they are growing before largescale adoption. In addition, low-P fertilizers may promote bluing of flowers in Al-sensitive Hydrangea macrophylla due to greater $\mathrm{Al}$ availability (Asen et al., 1960; Shanks et al., 1950). Hence, further research is needed on the feasibility of producing pink-flowered Hydrangea macrophylla when using a low-P CRF in an open-air nursery setting.

Our findings also suggest that a constant PWP concentration in pour-through leachate of $5 \mathrm{mg} \mathrm{L}^{-1}$, the minimum recommended concentration for CRF-fertilized containerized nursery-crops (Bilderback et al., 2013), is higher than necessary for producing the hydrangea clone used in this study. At the MACP site, hydrangea PWP concentrations were consistently less than $2 \mathrm{mg} \mathrm{L}^{-1}$ for CRF treatments that were sufficient for maximal growth. However, since PWP levels are dynamic relative to time, taxa and possibly plant growth stage, measuring PWP concentrations of CRF-fertilized containerized nursery crops is often an ineffective method for assessing P fertility. Results also indicate that $\mathrm{P}$ release pattern may differ for heterogeneous compared homogeneous CRFs, despite both having the same nutrient release longevity and coating material. Growth response of holly to CRF-P rate at the MACP site was inconsistent with results observed at the RV site and findings in scientific literature; hence, further research is needed to determine the optimal CRF-P rate for this taxon.

\section{Acknowledgements}

The authors thank Julie Brindley, Velva Groover, and Anna Birnbaum for technical assistance, as well as Saunders Brothers Nursery and Bailey Nursery for donating plants for this research. Funding was provided by the Virginia Agricultural Experiment Station, the Hatch Program and Clean Water3(SCRI 2014-51181-22372) of the National Institute of Food and Agriculture, U.S. Department of Agriculture, the Horticultural Research Institute, Virginia Agricultural Council, and the Virginia Nursery and Landscape Association.

\section{References}

Bryson, G.M., H.A. Mills, N.D. Sasseville, J.B. Jones, Jr., A.B. Barker. 2014. Plant analysis handbook III: A guide to sampling, preparation, analysis, interpretation and use of results of agronomic and horticultural crop plant tissue. Macro-Micro Publishing, Inc., Athens, GA

Asen, S., Stuart, N.W., Specht, A.W., 1960. Color of Hydrangea macrophylla sepals as influenced by the carry-over effects from summer applications of nitrogen, phosphorus, and potassium. Proc. Am. Soc. Hort. Sci. 76, 631-636.

Bi, G., Scagel, C.F., Fuchigami, L.H., Regan, R.P., 2007. Differences in growth, and nitrogen uptake and storage between two container-grown cultivars of Rhododendron. J. Environ. Hort. 25, 13-20.

Bilderback, T., Boyer, C., Chappell, M., Fain, G., Fare, D., Gilliam, C., Jackson, B.E., LeaCox, J., LeBude, A.V., Niemiera, A., Owen, J., Ruter, J., Tilt, K., Warren, S., White, S. Whitwell, T., Wright, R., Yeager, T., 2013. Best Management Practices: Guide for Producing Nursery Crops, 3rd ed. Southern Nursery Association, Acworth, GA.

Boesch, D.F., Brinsfield, R.B., Magnien, R.E., 2001. Chesapeake Bay eutrophication: scientific understanding, ecosystem restoration, and challenges for agriculture. J. Environ. Qual. 30, 303-320.

Broschat, T., 1995. Nitrate, phosphate, and potassium leaching from container-grown plants fertilized by several methods. Hort Science 30, 74-77.

Broschat, T., 2005. Rates of ammonium-nitrogen, nitrate-nitrogen, phosphorus, and potassium from two controlled-release fertilizers under different substrate environments. HortTechnology 15, 332-335.

Broschat, T.K., Moore, K.K., 2007. Release rates of ammonium-nitrogen, nitrate-nitrogen, phosphorus, potassium, magnesium, iron, and manganese from seven controlled-release fertilizers. Commun. Soil. Sci. Plant. Anal. 38, 843-850.

Cavins, T.J., Whipker, B.E., Fonteno, W.C., 2004. Establishment of calibration curves for comparing pour-through and saturated media extract nutrient values. Hort Science 39, 1635-1639.

Chen, L., Zeng, J., Xu, D.P., Zhao, Z.G., Guo, J.J., 2010. Macronutrient deficiency symptoms in Betula alnoides seedlings. J. Trop. For. Sci. 22, 403-413.

Clark, M.J., Zheng, Y., 2017. Effect of topdressed controlled-release fertilizer rates on nursery crop quality and growth and growing substrate nutrient status in the Niagara region, Ontario, Canada. Hort Science 52, 167-173.

Diara, C., Incrocci, L., Incrocci, G., Carmassi, G., Pardossi, A., Marzialetti, P., Cozzi, P., Fibbi, F., Clemens, R., 2014. Reduction of nutrient run-off by the use of coated slowrelease fertilizers on two container-grown nursery crops. Acta Hort. 1034, 85-92.

Dickey, R.D., Poole, R.T., Joiner, J.N., 1967. Effect of nitrogen, phosphorus and potassium levels on growth and chemical composition of Rhododendron indicum 'Formosa' and Viburnum suspensum. Proc. Amer. Soc. Hort. Sci. 91, 762-770.

Dirr, M.A., J.H. Kardos. 2015. Hydrangea macrophylla plant 'PIIHM-II'. US Plant Patent 25566. Date issued: 19 May.

Du, C., Zhou, J., Shaviv, Avi, 2006. Release characteristics of nutrients from polymercoated compound controlled release fertilizers. J. Polym Environ. 14, 223-230.

Ericsson, T., Ingestad, T., 1988. Nutrition and growth of birch seedlings at varied relative phosphorus addition rates. Physiol. Plant. 72, 227-235.

Fain, G.B., Gilliam, C.H., Tilt, K.M., Olive, J.W., Wallace, B., 2000. Survey of best management practices in container production nurseries. J. Environ. Hort. 18, 142-144.

Fonteno, W.C., Hardin, C.T., Brewster, J.P., 1995. Procedures for Determining Physical Properties of Horticultural Substrates Using the NCSU Porometer. Horticultural Substrates Laboratory. NC State University, Raleigh, NC.

Gilliam, C.H., Wright, R.D., 1978. Effects of three nitrogen levels on tissue nitrogen fluctuation during a flush of growth on 'Helleri' holly (Ilex crenata thumb.). Hort Science 13, 301-302

Groves, K.M., Warren, S.L., Bilderback, T.E., 1998a. Irrigation volume, application, and controlled-release fertilizer. I. Effect on plant growth and mineral nutrient content in containerized plant production. J. Environ. Hort. 16, 176-181.

Groves, K.M., Warren, S.L., Bilderback, T.E., 1998b. Irrigation volume, application, and controlled-release fertilizer. II. Effect on substrate solution nutrient concentration and water efficiency in containerized plant production. J. Environ. Hort. 16, 182-188.

Havis, J.R., Baker, J.H., 1985. Phosphorus requirement of Rhododendron 'victor' and Cotoneaster adpressa praecox grown in a perlite-peat medium. J. Environ. Hort. 3, 63-64.

Jarrell, W.M., Beverly, R.B., 1981. The dilution effect in plant nutrition studies. Adv. Agron. 34, 197-224.

Jiménez, S., Pérez, M., Plaza, B.M., Salinas, R., Lao, M.T., 2007. Empirical models of phosphorus uptake under different nitrogen sources in Dieffenbachia amoena 'Tropic snow'. Hort Science 42, 412-416.

Kim, H., Li, X., 2016. Effects of phosphorus on shoot and root growth, partitioning, and phosphorus utilization efficiency in lantana. Hort Science 51, 1001-1009. 
Kraus, H.T., Warren, S.L., Bjorkquist, G.J., Lowder, A.W., Tchir, C.M., Walton, K.N., 2011. Nitrogen : phosphorus : potassium ratios affect production of two herbaceous perennials. Hort Science 46, 776-783.

Leonard, M., Orfanedes, M., Yeager, T., 2007. Response of croton and coco plum to phosphorus. Proc. South. Nurs. Assoc. Res. Conf. 52, 531-534.

Mack, R., Owen, J.S., Niemiera, A.X., Latimer, J., 2017. Virginia nursery and greenhouse grower survey of best management practices. Hort Technology 27, 386-392.

Majsztrik, J.C., Lea-Cox, J.D., 2013. Water quality regulations in the Chesapeake Bay: working to more precisely estimate nutrient loading rates and incentivize best management practices in the nursery and greenhouse industry. Hort Science 48, 1097-1102.

Marschner, H., 2012. Mineral Nutrition of Higher Plants, 3rd ed. Academic Press, San Diego, CA.

Mathers, H.M., Yeager, T.H., Case, L.T., 2005. Improving irrigation water use in container nurseries. HortTechnology 15, 8-12.

Matysiak, B., 2015. Growth response of container grown Japanese azalea and euonymus and concentration of nitrates and phosphates in the runoff water under different irrigation and fertilization. J. Hort. Res. 23, 21-32.

Michalak, A.M., Anderson, E.J., Beletsky, D., Boland, S., Bosch, N.S., Bridgeman, T.B., Chaffin, J.D., Cho, K., Confesor, R., Daloglu, I., DePinto, J.V., Evans, M.A., Fahnenstiel, G.L., He, L., Ho, J.C., Jenkins, L., Johengen, T.H., Kuo, K.C., LaPorte, E., Liu, X., McWilliams, M.R., Moore, M.R., Posselt, D.J., Richards, R.P., Scavia, D., Steiner, A.L., Verhamme, E., Wright, D.M., Zagorski, M.A., 2015. Record-setting algal bloom in Lake Erie caused by agricultural and meteorological trends consistent with expected future conditions. Proc. Natl. Acad. Sci. 110, 6448-6452.

Naik, M.R., Kumar, B.K., Manasa, K., 2017. Polymer coated fertilizers as advance technique in nutrient management. Asian J. Soil. Sci. 12, 228-232.

Newman, J.P., Albano, J.P., Merhaut, D.J., Blythe, E.K., 2006. Nutrient release from controlled-release fertilizers in a neutral-pH substrate in an outdoor environment: I. Leachate electrical conductivity, $\mathrm{pH}$, and nitrogen, phosphorus, and potassium concentrations. HortScience 41, 1674-1682.

Niemiera, A.X., 2009. Japanese holly (Ilex crenata). Va. Cooperative Ext 2901-1052.

Niu, F., Zhang, D., Li, Z., Van Iersel, M.W., Alem, P., 2015. Morphological response of eucalypts seedlings to phosphorus supply through hydroponic system. Sci. Hort. 194, 295-303.

Owen, J.S., Warren, S.L., Bilderback, T.E., Albano, J.P., 2008. Phosphorus rate, leaching fraction, and substrate influence on influent quantity, effluent nutrient content, and response of a containerized woody ornamental crop. Hort Science 43, 906-912.

Ristvey, A.G., Lea-Cox, J.D., Ross, D.S., 2004. Nutrient uptake, partitioning and leaching losses from container-nursery production systems. Acta Hort. 630, 321-328.

Ristvey, A.G., Lea-Cox, J.D., Ross, D.S., 2007. Nitrogen and phosphorus uptake efficiency and partitioning of container-grown azalea during spring growth. J. Amer. Soc. Hort Sci. 132, 563-572.

Shanks, J.B., Haun, J.R., Link, C.B., 1950. A preliminary study on the mineral nutrition of Hydrangeas. Proc. Amer. Soc. Hort. Sci. 58, 457-465.

Sharma, J., Bolques, A., 2007. Runoff quality at container plant nurseries. Proc. South. Nurs. Assoc. Res. Conf. 52, 138-142.

Shreckhise, J.H., Owen, J.S., Niemiera, A.X., 2018. Growth response of three containerized woody plant taxa to varying low phosphorus fertilizer concentrations. HortScience (In press).

Sonneveld, C., Voogt, W., 2009. Plant Nutrition of Greenhouse Crops. Springer, Dordrecht, The Netherlands.

Tolman, D.A., Niemiera, A.X., Wright, R.D., 1990. Influence of plant age on nutrient absorption for marigold seedlings. HortScience 25, 1612-1613.

Tyler, H.H., Warren, S.L., Bilderback, T.E., 1996. Reduced leaching fractions improve irrigation use efficiency and nutrient efficacy. J. Environ. Hort. 14, 199-204.

Warren, S.L., Bilderback, T.E., Tyler, H.H., 1995. Efficacy of three nitrogen and phosphorus sources in container-grown azalea production. J. Environ. Hort. 13, 147-151.

Warren, S.L., Bilderback, T.E., Kraus, H.H., 2001. Method of fertilizer application affects nutrient losses of controlled-release fertilizer. Acta Hort. 548, 349-355.

Wright, R.D., 1986. The pour-through nutrient extraction procedure. HortScience 21, 227-229.

Wright, R.D., Browder, J.F., Jackson, B.E., 2006. Ground pine chips as a substrate for container-grown woody nursery crops. J. Environ. Hort. 24, 181-184.

Yeager, T.H., Barrett, J.E., 1984. Phosphorus leaching from ${ }^{32} \mathrm{P}$-superphosphate-amended soilless container media. HortScience 19, 216-217.

Yeager, T.H., Barrett, J.E., 1985. Influence of incubation time on phosphorus leaching from a container medium. J. Environ. Hort. 3, 186-187.

Yeager, T.H., Wright, R.D., 1982a. Pine bark - phosphorus relationships. Commun. Soil. Sci. Plant. Anal. 13, 57-66.

Yeager, T.H., Wright, R.D., 1982b. Phosphorus requirement of Ilex crenata thunb. Cv. Helleri grown in a pine bark medium. J. Amer. Soc. Hort. Sci. 107, 558-562. 